\title{
Triple-Negative Breast Cancer: Current Understanding and Future Therapeutic Breakthrough Targeting Cancer Stemness
}

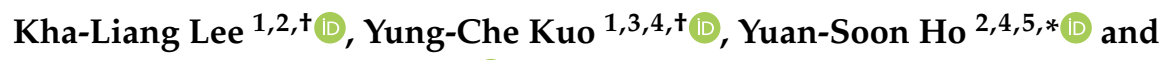 \\ Yen-Hua Huang 1,2,3,4,6,7,8,9,*(D) \\ 1 Department of Biochemistry and Molecular Cell Biology, School of Medicine, College of Medicine, \\ Taipei Medical University, Taipei 11031, Taiwan \\ 2 Graduate Institute of Medical Sciences, College of Medicine, Taipei Medical University, Taipei 11031, Taiwan \\ 3 TMU Research Center for Cell Therapy and Regeneration Medicine, Taipei Medical University, \\ Taipei 11031, Taiwan \\ 4 TMU Research Center of Cancer Translational Medicine, Taipei Medical University, Taipei 11031, Taiwan \\ 5 School of Medical Laboratory Science and Biotechnology, College of Medical Science and Technology, \\ Taipei Medical University, Taipei 11031, Taiwan \\ 6 International PhD Program for Cell Therapy and Regeneration Medicine, College of Medicine, \\ Taipei Medical University, Taipei 11031, Taiwan \\ 7 Center for Reproductive Medicine, Taipei Medical University Hospital, Taipei Medical University, \\ Taipei 11031, Taiwan \\ 8 Comprehensive Cancer Center of Taipei Medical University, Taipei 11031, Taiwan \\ 9 Ph.D. Program for Translational Medicine, College of Medical Science and Technology, \\ Taipei Medical University, Taipei 11031, Taiwan \\ * Correspondence: hoyuansn@tmu.edu.tw (Y.-S.H.); rita1204@tmu.edu.tw (Y.-H.H.); \\ Tel.: +886-2-2736-1661 (Ext. 3327) (Y.-S.H.); +886-2-2736-1661 (Ext. 3150) (Y.-H.H.) \\ + The authors contributed equally to this article.
}

Received: 2 August 2019; Accepted: 30 August 2019; Published: 9 September 2019

\begin{abstract}
Triple-negative breast cancer (TNBC) is cancer that tested as negative for estrogen receptors (ER), progesterone receptors (PR), and excess human epidermal growth factor receptor 2 (HER2) protein which accounts for $15 \%-20 \%$ of all breast cancer cases. TNBC is considered to be a poorer prognosis than other types of breast cancer, mainly because it involves more aggressive phenotypes that are similar to stem cell-like cancer cells (cancer stem cell, CSC). Thus, targeted treatment of TNBC remains a major challenge in clinical practice. This review article surveys the latest evidence concerning the role of genomic alteration in current TNBC treatment responses, current clinical trials and potential targeting sites, CSC and drug resistance, and potential strategies targeting CSCs in TNBC. Furthermore, the role of insulin-like growth factor 1 receptor (IGF-1R) and nicotinic acetylcholine receptors (nAChR) in stemness expression, chemoresistance, and metastasis in TNBC and their relevance to potential treatments are also discussed and highlighted.
\end{abstract}

Keywords: TNBC; Recurrence; Resistance; Cancer stem cell; IGF-1R; nAChR

\section{Introduction}

Breast cancer is the most frequently diagnosed malignancy and the main cause of cancer-related death in women. Globally, approximately 2.1 million new female breast cancer cases and 627,000 deaths were estimated to have occurred in 2018 [1]. Recurrence and metastasis are the major cause of these deaths. Approximately $15 \%-20 \%$ of these patients could be classified as "triple-negative." The diagnosis is made by observing exclusion of the expression and/or amplification of three biomarkers 
(estrogen receptor [ER], progesterone receptor [PR], and human epidermal growth factor receptor 2 [HER2] protein) [2].

So-called triple negative breast cancer (TNBC) is more commonly diagnosed in women younger than 40 years compared to hormone-positive breast cancer [3]. The histology is usually high grade and most commonly interpreted as infiltrating ductal carcinoma, which exhibits geographic necrosis, a pushing border of invasion, and a stromal lymphocytic response. Clinically, TNBC tends to act more violently than other types of breast cancer and is characterized by a high risk of relapse, short progression-free survival (PFS), and overall survival (OS) [4]. One-half of patients with early-stage TNBC (stages I to III) experience disease recurrence, and 37\% of patients experience a 5-year mortality rate after surgery [5]. Also, patients with metastatic TNBC have short PFS after failure of first-line chemotherapy (median PFS, 3 to 4 months), suggesting the highly unmet need for the development of a drug targeting TNBC [6].

TNBC is clinically heterogeneous, with deviations in morphology, mutational phenotype, and signaling profiles between tumors. Notably, the diagnostic criteria have not been developed to distinguish a distinct biologic subtype of breast cancer-a "triple-negative" phenotype. A histologic subtype, medullary carcinoma, despite generally being triple-negative, has a very good prognosis [7]. Due to next-generation sequencing, our understanding of the heterogeneity of TNBC is evolving. For example, TNBC can be clustered into at least six subtypes on the basis of gene ontologies and expression profiling: basal-like 1, basal-like 2, immune modulator, mesenchymal, mesenchymal stem-like, and luminal androgen receptor [8]. Additional subtypes include claudin-low and interferon-rich subtypes [9,10]. Furthermore, the tumor suppressor gene p53 (TP53) and several DNA repair genes, particularly the $B R C A$ genes, are either mutated or abnormally expressed in TNBC. These molecular characteristics may influence chemotherapy sensitivity to direct DNA-damaging agents such as platinum [11].

\section{Molecular Classification of TNBC}

In 2000, Perou et al. discovered a classification of breast cancer based on gene expression patterns. The triple-negative clinical phenotype mostly comprises the basal cell-like subgroup [12]. However, triple-negative and basal cell breast cancers are not synonymous. Immunohistochemical (IHC) and molecular profiling studies have suggested that only a subgroup of TNBC expresses the combination of basal cell markers (for instance, CK5 and CK14) [13]: both categories have up to 30\% discordance [14]. In addition, basal-like can further divide into KRT5 $/ 6^{+}$, EGFR ${ }^{-}$, and c-KIT ${ }^{-}$subgroups [15].

During the last decade, numerous studies have developed exclusive molecular classifications for TNBC. Rody et al. first distinguished a molecular subgroup by defining 16 metagenes within the group [16]. Later, Lehmann et al. identified seven molecular subgroups: unstable cluster (UNS), basal-like 1 (BL1), basal-like 2 (BL2), immunomodulatory (IM), mesenchymal (MES) like, mesenchymal stem like (MSL), and luminal androgen receptor (LAR) [8]. In addition, in another intrinsic subgroup, approximately $70 \%$ of claudin-low tumors are TNBC, with a high frequency of metaplastic and medullary differentiation [2,10]. The IM and MSL subtypes have since been refined [17]. Burstein et al. utilized nonnegative matrix factorization and defined four subgroups: basal-like immune active, basal-like immune suppressed, mesenchymal, and luminal AR [18]. Another study showed basal A, basal B, basoluminal, and luminal subtypes existing in TNBC [19]. Most recently, Prado-Vazquez et al. applied probabilistic graphical models to explore the molecular analysis of TNBC from the perspective of a CSC hypothesis. They proposed at least two independent biological levels-cellular and immune-to stratify the prognostic and possible therapeutic classification [20]. The aforementioned subtypes display distinct therapeutic responses and pathological complete response $(\mathrm{pCR})$ rates after neoadjuvant chemotherapy [21]. In the Lehmann classification, cell cycle and DNA damage response genes are highly expressed in BL1 tumors, with a high mitotic index. Clinically, patients with BL1 subtypes exhibit good response to antimitotic agents such as taxanes (paclitaxel or docetaxel) and the DNA-damaging agent cisplatin, achieving approximately one half of $\mathrm{pCR}$ rates after neoadjuvant 
chemotherapy. Additionally, survival-mediated receptor tyrosine kinases, proliferation genes, and metabolic signaling genes are enriched in BL2 tumors. These patients, however, seldom achieve a pCR. MSL subtypes are sensitive to sarcoma family kinase (SRC) and phosphoinositide 3-kinase $(\mathrm{PI} 3 \mathrm{~K}) /$ mammalian target of rapamycin (mTOR) inhibitor tumors and thus have moderate $\mathrm{pCR}$ rates (23\%-31\%). In addition, expression of epithelial-mesenchymal transition (EMT) markers is enhanced in the MES and MSL subtypes, with low expression levels for proliferation-related genes and accompanied by a low mitotic index [8]. Furthermore, transforming growth factor $\beta$ (TGF- $\beta$ ) and receptor type III (TGFBRIII) were demonstrated to drive migration and invasion of MSL cell lines both in vitro and in vivo [22]. These studies clearly demonstrated that in patients receiving the same treatment, the heterogeneous nature of the effect of molecular and genomic expression was evident. Recently, a Phase Ib/II, open-label, umbrella study (NCT03805399) was conducted to evaluate multiple targeted treatments in patients with specific subtypes of TNBC according to Fudan University Shanghai Cancer Center 500+ gene panel testing and IHC subtype staining. Despite these extensive studies, the clinical effect of the designation of TNBC molecular subtypes remains largely undetermined, and future studies are required.

\section{Response to Treatment: Clinical Practice and Genomic Alteration of TNBC}

Treatment for TNBC remains a major clinical challenge due to the lack of causally proven oncogenic drivers through which to target the vast disease heterogeneity $[8,23]$. To date, the principles for the surgical management of and radiation therapy options for TNBC are applied in a similar manner across various breast cancer subtypes. In nonmetastatic settings, neoadjuvant or adjuvant chemotherapy is typically administered for women with TNBC $\geq 0.5 \mathrm{~cm}$ or node-positive TNBC (regardless of tumor size). Typically, tumor size, lymph node status, grade, overall performance status, and the presence or absence of medical comorbidities determines the chemo regimens used. These patients have a higher risk of relapse compared with other breast cancer phenotypes and are not candidates for other forms of adjuvant therapy (i.e., HER2-directed treatment or endocrine therapy) [5,24]. Interestingly, in patients with metastatic breast cancer, there is a possible discordance of ER, PR, and HER2 markers between primary and metastatic disease- $12.6 \%, 31.2 \%$, and $5.5 \%$, respectively $(p<0.001)$. Thus, a confirmatory biopsy of a suspected lesion should be obtained when possible [25].

Because patients with TNBC commonly do not achieve a pCR following chemotherapy, the selection of chemotherapy to use against different TNBC subtypes is being debated [21]. Neoadjuvant anthracycline-based chemotherapy is related to a higher PCR in TNBC compared with luminal non-TNBC subtypes and is therefore reasonable to consider. In the adjuvant therapy space, the principles for non-TNBC apply equally to TNBC, and these can include administering anthracyclines, taxanes, and/or platinum compounds to disrupt cancer cell survival $[5,26,27]$. The addition of platinum compounds to standard chemotherapy has doubled pCR rates in patients with TNBC [26], but those who fail to achieve pCR exhibit worse outcomes compared with other subtypes of breast cancer [5].

Several studies, including in vitro and in vivo studies and clinical trials, have defined genomic effects inherent to TNBC response to treatment. Silver et al. demonstrated that the alteration of $B R C A 1$ expression, caused by promoter methylation and $p 53$ mutations, conferred good prognosis to cisplatin treatment [27]. Similarly, CD73 expression has been associated with doxorubicin resistance in patients with TNBC [28]. Another study focusing on genomic adaptations in basal-like tumors revealed mutations of $p 53$ and PIK3CA, loss of PTEN and RB1, amplification of cyclin E1, and increased expression of MYC and HIF1- $\alpha$ [29]. Furthermore, Balko et al. analyzed residual breast cancer after neoadjuvant chemotherapy and identified the additional amplification of several genes (CDK4, MCL1, $J A K 2, A K T 1$, and EGFR) and loss of mutations in BRCA1/2, ATM, and CDKN2A [30]. These findings have encouraged more research efforts to identify effective therapeutic strategies for TNBC. 


\section{Current Clinical Trials in Triple-Negative Breast Cancer}

A summary of current trials of single-agent treatments or combinations of different target therapeutic reagents and chemotherapy is provided in Table 1 . We describe these targets and treatments in a cell function-based manner, emphasizing DNA repair and damage, growth factor and angiogenesis, specific hormone receptors, and immune molecular checkpoints (Figure 1).

Table 1. The ongoing clinical trials in triple-negative breast cancer.

\begin{tabular}{|c|c|c|c|c|c|}
\hline Target & Major Drug & Combinational Drug & Phase & NCT Identifiers & Status \# \\
\hline \multicolumn{6}{|l|}{ BRCA1/2 } \\
\hline \multirow{24}{*}{ PARP } & BGB290 & \pm Temozolomide & $\mathrm{I} / \mathrm{II}$ & NCT03150810 & $\mathrm{R}$ \\
\hline & \multirow{4}{*}{ BMN-673 } & - & II & NCT02401347 & $\mathrm{R}$ \\
\hline & & \pm Carboplatin + Paclitaxel & I & NCT02358200 & $\mathrm{Ac} / \mathrm{NR}$ \\
\hline & & \pm CB-839 (GLS1i) & $\mathrm{I} / \mathrm{II}$ & NCT03875313 & $\mathrm{R}$ \\
\hline & & \pm ZEN003694 (BETi) & II & NCT03901469 & $\mathrm{R}$ \\
\hline & Niraparib & \pm Pembrolizumab & $\mathrm{I} / \mathrm{II}$ & NCT02657889 & $\mathrm{Ac} / \mathrm{NR}$ \\
\hline & \multirow{12}{*}{ Olaparib } & - & II & NCT00679783 & Ac/NR \\
\hline & & $\begin{array}{l} \pm \text { AZD2014 (mTORi) } \pm \text { AZD5363 } \\
(\text { AKTi) }\end{array}$ & $\mathrm{I} / \mathrm{II}$ & NCT02208375 & $\mathrm{Ac} / \mathrm{NR}$ \\
\hline & & \pm AZD6738 \pm AZD1775 & II & NCT03330847 & $\mathrm{R}$ \\
\hline & & \pm BKM120 (PI3Ki) \pm BYL719 (PI3Ki) & I & NCT01623349 & $\mathrm{Ac} / \mathrm{NR}$ \\
\hline & & \pm Carboplatin \pm Paclitaxel & I & NCT00516724 & $\mathrm{Ac} / \mathrm{NR}$ \\
\hline & & \pm Carboplatin \pm Paclitaxel & II/III & NCT03150576 & $\mathrm{R}$ \\
\hline & & \pm Cediranib (VGEFi) & $\mathrm{I} / \mathrm{II}$ & NCT01116648 & $\mathrm{Ac} / \mathrm{NR}$ \\
\hline & & \pm Cediranib \pm Durvalumab & $\mathrm{I} / \mathrm{II}$ & NCT02484404 & $\mathrm{R}$ \\
\hline & & \pm Durvalumab (anti PD-1) & I & NCT03544125 & $\mathrm{R}$ \\
\hline & & \pm Durvalumab (anti PD-1) & II & NCT03801369 & $\mathrm{R}$ \\
\hline & & \pm Durvalumab (anti PD-1) & II & NCT03167619 & $\mathrm{R}$ \\
\hline & & \pm Onalespib (HSP90i) & I & NCT02898207 & $\mathrm{R}$ \\
\hline & Rucaparib & \pm Cisplatin & II & NCT01074970 & $\mathrm{Ac} / \mathrm{NR}$ \\
\hline & \multirow{5}{*}{ Veliparib } & $\begin{array}{l} \pm \text { Carboplatin } \pm \text { Cyclophosphamide } \\
\pm \text { Doxorubicin } \pm \text { Paclitaxel }\end{array}$ & II & NCT01818063 & $\mathrm{Ac} / \mathrm{NR}$ \\
\hline & & $\begin{array}{l} \pm \text { Carboplatin } \pm \text { Cyclophosphamide } \\
\pm \text { Doxorubicin } \pm \text { Paclitaxel }\end{array}$ & III & NCT02032277 & $\mathrm{Ac} / \mathrm{NR}$ \\
\hline & & \pm Cisplatin & II & NCT02595905 & $\mathrm{R}$ \\
\hline & & \pm Irinotecan Hydrochloride & I & NCT00576654 & $\mathrm{Ac} / \mathrm{NR}$ \\
\hline & & \pm Lapatinib (EGFR/HER2i) & Pilot study & NCT02158507 & $\mathrm{Ac} / \mathrm{NR}$ \\
\hline \multicolumn{6}{|c|}{ CHK1 and WEE1 } \\
\hline CHK1 & LY2880070 & \pm Gemcitabine & $\mathrm{I} / \mathrm{II}$ & NCT02632448 & $\mathrm{R}$ \\
\hline CHK1/2 & LY2606368 & - & II & NCT02203513 & $\mathrm{R}$ \\
\hline \multirow{2}{*}{ WEE1 } & \multirow{2}{*}{ AZD1775 } & - & I & NCT02482311 & $\mathrm{Ac} / \mathrm{NR}$ \\
\hline & & \pm Cisplatin & II & NCT03012477 & $\mathrm{Ac} / \mathrm{NR}$ \\
\hline \multicolumn{6}{|c|}{ Cyclin-dependent kinases } \\
\hline \multirow{5}{*}{ CDKs } & Abemaciclib & - & II & NCT03130439 & $\mathrm{R}$ \\
\hline & PF-06873600 & \pm Endocrine Therapy & II & NCT03519178 & $\mathrm{R}$ \\
\hline & Ribociclib & \pm Bicalutamide (ARi) & $\mathrm{I} / \mathrm{II}$ & NCT03090165 & $\mathrm{Ac} / \mathrm{NR}$ \\
\hline & SHR6390 & \pm SHR3680 (ARi) & $\mathrm{I} / \mathrm{II}$ & NCT03805399 & $\mathrm{R}$ \\
\hline & Trilaciclib & \pm Gemcitabine + Carboplatin & II & NCT02978716 & $\mathrm{Ac} / \mathrm{NR}$ \\
\hline
\end{tabular}


Table 1. Cont

\begin{tabular}{|c|c|c|c|c|c|}
\hline Target & Major Drug & Combinational Drug & Phase & NCT Identifiers & Status $\#$ \\
\hline \multicolumn{6}{|c|}{ Androgen receptor } \\
\hline \multirow{7}{*}{ Androgen } & Bicalutamide & - & III & NCT03055312 & $\mathrm{R}$ \\
\hline & CR1447(ARM) & - & II & NCT02067741 & $\mathrm{Ac} / \mathrm{NR}$ \\
\hline & $\begin{array}{l}\text { Darolutamide } \\
\text { (NSAA) }\end{array}$ & \pm Capecitabine & II & NCT03383679 & $\mathrm{R}$ \\
\hline & \multirow{3}{*}{ Enzalutamide } & - & II & NCT02750358 & $\mathrm{Ac} / \mathrm{NR}$ \\
\hline & & - & II & NCT01889238 & $\mathrm{Ac} / \mathrm{NR}$ \\
\hline & & \pm Paclitaxel & II & NCT02689427 & $\mathrm{R}$ \\
\hline & $\begin{array}{l}\text { GTx-024 } \\
\text { (SARM) }\end{array}$ & \pm Pambrolizumab (anti PD-1) & II & NCT02971761 & $\mathrm{R}$ \\
\hline \multicolumn{6}{|c|}{ Growth factors and angiogenesis } \\
\hline \multirow{6}{*}{ EGFR } & Cetuximab & \pm Ixabepilone & II & NCT01097642 & $\mathrm{Ac} / \mathrm{NR}$ \\
\hline & Icotinib & - & II & NCT02362230 & $\mathrm{R}$ \\
\hline & \multirow{3}{*}{ Panitumumab } & \pm Gemcitabine + Cisplatin & II & NCT02546934 & $\mathrm{R}$ \\
\hline & & \pm Carboplatin + Paclitaxel & II & NCT02593175 & $\mathrm{R}$ \\
\hline & & $\begin{array}{l} \pm \text { Carboplatin + Paclitaxel }+ \\
\text { Doxorubicin + Cyclophosphamide }\end{array}$ & II & NCT02876107 & $\mathrm{R}$ \\
\hline & SCT200 & - & II & NCT03692689 & $\mathrm{R}$ \\
\hline HER2 & Trastuzumab & \pm Paclitaxel + Cyclophosphamide & II & NCT01750073 & $\mathrm{R}$ \\
\hline VEGF & Bevacizumab & \pm Paclitaxel + Erlotinib (EGFRi) & II & NCT00733408 & $\mathrm{Ac} / \mathrm{NR}$ \\
\hline \multirow{2}{*}{ VEGFR2 } & \multirow{2}{*}{ Apatinib } & \pm Fluzoparib (PARPi) & I & NCT03075462 & $\mathrm{R}$ \\
\hline & & \pm Vinorelbine & II & NCT03254654 & $\mathrm{R}$ \\
\hline \multicolumn{6}{|c|}{ SRC and WNT signaling } \\
\hline SRC & Dasatinib & - & II & NCT02720185 & $\mathrm{R}$ \\
\hline \multirow{2}{*}{ WNT } & \multirow{2}{*}{ LGK974 } & \pm PDR001 (anti-PD-1) & I & NCT01351103 & $\mathrm{R}$ \\
\hline & & \pm Gedatolisib (PI3Ki) & I & NCT03243331 & $\mathrm{R}$ \\
\hline \multicolumn{6}{|c|}{ PI3K/AKT/mTOR pathway } \\
\hline PIK3CA & Taselisib & \pm Enzalutamide (ARi) & $\mathrm{I} / \mathrm{II}$ & NCT02457910 & $\mathrm{R}$ \\
\hline \multirow{2}{*}{ РIK3СВ } & IPI-549 & \pm Nivolumab (anti PD-1) & I & NCT02637531 & $\mathrm{R}$ \\
\hline & PQR309 & \pm Eribulin & $\mathrm{I} / \mathrm{II}$ & NCT02723877 & $\mathrm{R}$ \\
\hline \multirow{4}{*}{ PI3K } & \multirow{2}{*}{ AZD8186 } & - & I & NCT01884285 & $\mathrm{R}$ \\
\hline & & \pm Docetaxel & I & NCT03218826 & $\mathrm{R}$ \\
\hline & BKM120 & $\begin{array}{l} \pm \text { Capecitabine + Trastuzumab } \\
\text { (HER2i) }\end{array}$ & II & NCT02000882 & $\mathrm{Ac} / \mathrm{NR}$ \\
\hline & CUDC-907 & - & I & NCT02307240 & $\mathrm{Ac} / \mathrm{NR}$ \\
\hline \multirow{6}{*}{ AKT } & ARQ092 & \pm Carboplatin + Paclitaxel & $\mathrm{Ib}$ & NCT02476955 & $\mathrm{R}$ \\
\hline & AZD5363 & \pm Paclitaxel & II & NCT02423603 & $\mathrm{Ac} / \mathrm{NR}$ \\
\hline & GSK2141795 & \pm Trametinib (MEKi) & II & NCT01964924 & $\mathrm{Ac} / \mathrm{NR}$ \\
\hline & \multirow{3}{*}{ Ipatasertib } & - & II & NCT02162719 & $\mathrm{Ac} / \mathrm{NR}$ \\
\hline & & \pm Carboplatin + Paclitaxel & $\mathrm{I} / \mathrm{II}$ & NCT03853707 & $\mathrm{R}$ \\
\hline & & \pm Paclitaxel & $\mathrm{II} / \mathrm{III}$ & NCT03337724 & $\mathrm{R}$ \\
\hline \multirow{6}{*}{ mTOR } & AZD2014 & \pm Selumetinib (ERKi) & $\mathrm{I} / \mathrm{II}$ & NCT02583542 & $\mathrm{Ac} / \mathrm{NR}$ \\
\hline & \multirow{3}{*}{ Everolimus } & \pm Cisplatin + Paclitaxel & I & NCT02120469 & $\mathrm{Ac} / \mathrm{NR}$ \\
\hline & & \pm Cisplatin + Paclitaxel & II & NCT02531932 & $\mathrm{R}$ \\
\hline & & $\begin{array}{l} \pm \text { Doxorubicin + Bevacizumab } \\
\text { (VEGFi) }\end{array}$ & II & NCT02456857 & $\mathrm{R}$ \\
\hline & \multirow[t]{2}{*}{ Gedatolisib } & $\begin{array}{l} \pm \text { Docetaxel + Cisplatin }+ \\
\text { Dacomitinib (EGFRi) }\end{array}$ & I & NCT01920061 & $\mathrm{R}$ \\
\hline & & $\begin{array}{l} \pm \text { Tak-117 (PI3Ki) + Cisplatin }+ \\
\text { Paclitaxel }\end{array}$ & II & NCT03193853 & $\mathrm{R}$ \\
\hline
\end{tabular}


Table 1. Cont.

\begin{tabular}{|c|c|c|c|c|c|}
\hline Target & Major Drug & Combinational Drug & Phase & NCT Identifiers & Status $\#$ \\
\hline \multicolumn{6}{|c|}{ Immune checkpoint } \\
\hline \multirow{15}{*}{ PD-1 } & \multirow{2}{*}{ Nivolumab } & \pm Capecitabine & II & NCT03487666 & $\mathrm{R}$ \\
\hline & & \pm Carboplatin & I & NCT03414684 & $\mathrm{R}$ \\
\hline & PDR001 & - & $\mathrm{I} / \mathrm{II}$ & NCT02404441 & $\mathrm{Ac} / \mathrm{NR}$ \\
\hline & \multirow{11}{*}{ Pembrolizumab } & - & I & NCT03197389 & $\mathrm{R}$ \\
\hline & & - & II & NCT02447003 & $\mathrm{Ac} / \mathrm{NR}$ \\
\hline & & - & II & NCT02644369 & $\mathrm{Ac} / \mathrm{NR}$ \\
\hline & & - & III & NCT02555657 & $\mathrm{Ac} / \mathrm{NR}$ \\
\hline & & \pm Capecitabine \pm Paclitaxel & $\mathrm{I} / \mathrm{II}$ & NCT02734290 & $\mathrm{R}$ \\
\hline & & $\begin{array}{l} \pm \text { Doxorubicin } \pm \text { Aromatase } \\
\text { inhibitors }\end{array}$ & II & NCT02648477 & $\mathrm{R}$ \\
\hline & & $\begin{array}{l} \pm \text { Nab-paclitaxel (or Paclitaxel) }+ \\
\text { Carboplatin }+ \text { Doxorubicin }+ \\
\text { Cyclophosphamide }\end{array}$ & I & NCT02622074 & $\mathrm{Ac} / \mathrm{NR}$ \\
\hline & & $\begin{array}{l} \pm \text { Nab-paclitaxel }(\text { or Paclitaxel }) \pm \\
\text { Gemcitabine }+ \text { Carboplatin }\end{array}$ & III & NCT02819518, & $\mathrm{Ac} / \mathrm{NR}$ \\
\hline & & $\begin{array}{l} \pm \text { Paclitaxel }+ \text { Carboplatin } \pm \\
\text { Doxorubicin } \pm \text { Epirubicin }+ \\
\text { Cyclophosphamide }\end{array}$ & III & NCT03036488 & $\mathrm{Ac} / \mathrm{NR}$ \\
\hline & & \pm Lenvatinib (TKI) & II & NCT03797326 & $\mathrm{R}$ \\
\hline & & \pm PVX-410 Vaccine & I & NCT03362060 & $\mathrm{R}$ \\
\hline & SHR1210 & \pm Apatinib (TKI) & II & NCT03394287 & $\mathrm{Ac} / \mathrm{NR}$ \\
\hline \multirow{6}{*}{ PD-L1 } & \multirow{2}{*}{ Atezolizumab } & \pm Carboplatin & II & NCT03206203 & $\mathrm{R}$ \\
\hline & & $\begin{array}{l} \pm \text { Carboplatin + Cyclophosphamide } \\
\pm \text { Paclitaxel }\end{array}$ & II & NCT01898117 & $\mathrm{R}$ \\
\hline & \multirow{3}{*}{ Durvalumab } & $\begin{array}{l} \pm \text { Oleclumab + Paclitaxel }+ \\
\text { Carboplatin }\end{array}$ & I/II & NCT03616886 & $\mathrm{R}$ \\
\hline & & \pm Paclitaxel & $\mathrm{I} / \mathrm{II}$ & NCT02628132 & $\mathrm{R}$ \\
\hline & & - & II & NCT02685059 & $\mathrm{Ac} / \mathrm{NR}$ \\
\hline & FAZ053 & \pm PDR001 & I & NCT02936102 & $\mathrm{Ac} / \mathrm{NR}$ \\
\hline
\end{tabular}

\#, R: recruiting; Ac/NR: active, not recruiting. 


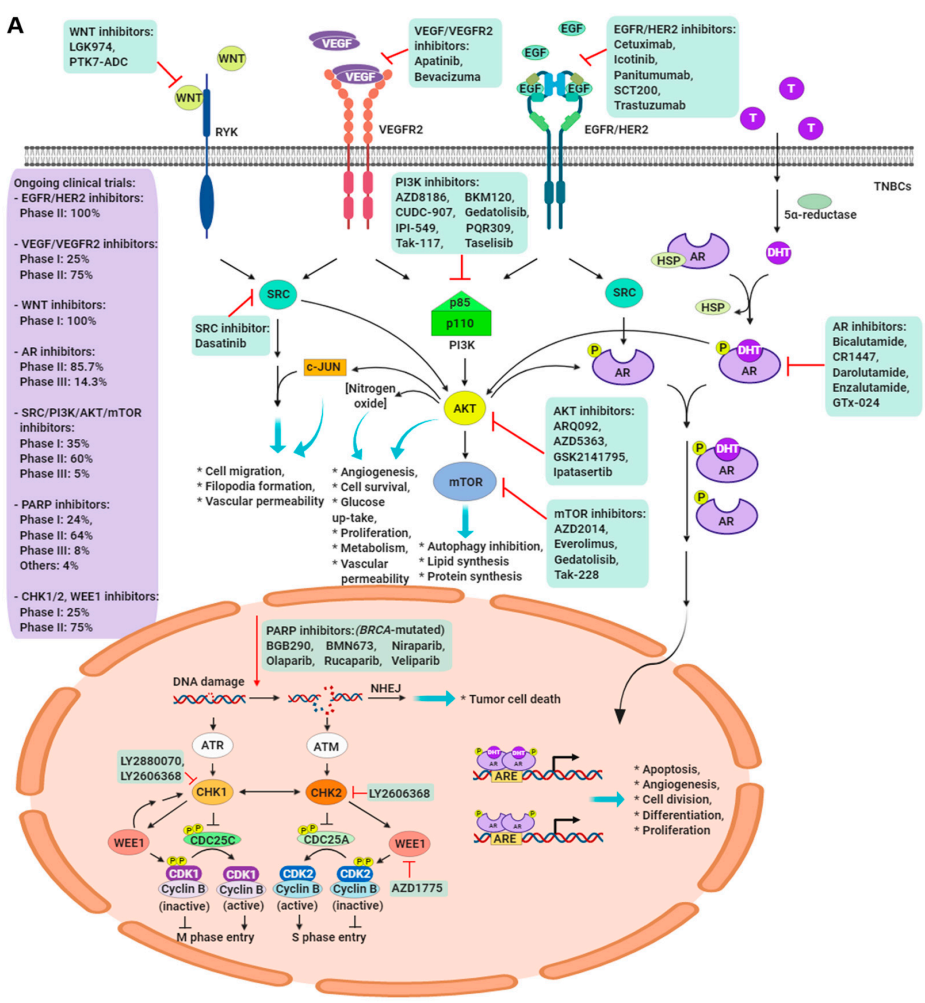

B
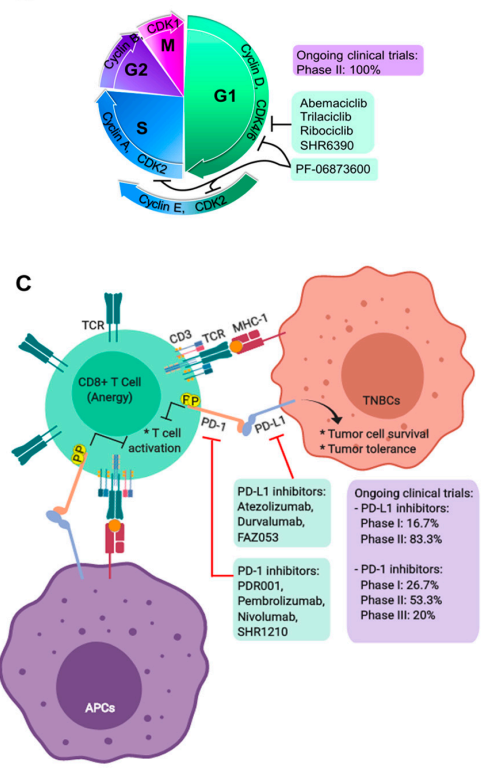

Figure 1. Diagram of ongoing clinical trials in TNBCs. (A) System view of signaling pathways activated by extracellular stimuli, which triggered multiple biological functions through central hub AKT or subsequent effectors. Numerous inhibitors attempt to attack these critical molecules in TNBCs, and ongoing phases of clinical trials for categorized inhibitors have also revealed the same. (B) Disruption of cell cycle by CDK inhibitors in TNBC trials. (C) Blockade of immune checkpoints in cancer immunotherapy. Prevention of PD-1/PD-L1 signaling transduction from inhibitors could activate $\mathrm{CD}^{+} \mathrm{T}$ cells to kill TNBC tumor cells.

\section{Targeting the BRCA1/2 Pathway}

\subsection{PARP Inhibitors}

Inhibition of PARP1 could induce double-strand DNA breaks, where DNA damage is repaired through a BRCA pathway-dependent homologous recombination mechanism under normal circumstances. Therefore, inhibition of PARP is particularly useful in BRCA-mutated breast cancer with aberrant DNA damage responses (DDR) [31-33]. Given the shared clinicopathologic characteristics of $B R C A$-mutated breast cancer and TNBC, the efficacy and safety of PARP inhibition is being tested in both settings. Among the subset of $121 B R C A$ mutation carriers with metastatic triple-negative disease in the OlympiAD trial has been grouped to anthracycline and a taxane in either the adjuvant or metastatic setting. Those that were randomly assigned to olaparib exhibited improved PFS relative to those receiving chemotherapy (HR for progression or death $0.43,95 \% \mathrm{CI}=0.29-0.63$ ) $[34,35]$. Notably, the study also indicated positive results for patients with hormone receptor-positive, HER2-negative disease; however, the improvements associated with olaparib were stronger in the triple-negative population. To date, several other PARP inhibitors are in clinical development [34-42].

\subsection{Growth Factors and Angiogenesis}

The epidermal growth factor receptor (EGFR/HER1) may be the most well-known protein that is overexpressed in cancers, and for which several monoclonal antibodies and small-molecule inhibitors exist. Several phase II clinical trials have assessed the efficacy of cetuximab, an anti-EGFR monoclonal antibody, which has exhibited modest activity in combination with chemotherapy against advanced 
TNBC $[43,44]$. In addition, VEGF and VEGFR that play roles in angiogenesis are considered an important target for cancer therapy. However, to date, prospective studies have not shown that the incorporation of angiogenesis inhibitors has an effect on OS for women with TNBC. Of agents in this class, VEGF antibody (bevacizumab) has been the most widely studied. Unfortunately, research results have consistently suggested that although incorporation of bevacizumab can improve PFS, it has virtually no effect on OS [45-49].

\subsection{Androgen Receptor Inhibitor}

Both normal and malignant breast tissue express the androgen receptor (AR) [50]. Luminal hormone receptor-positive breast cancers more commonly express AR (91\%), TNBC expresses AR approximately $30 \%$ of the time [51]. Interestingly, prognosis for those with AR-positive TNBC has been shown to be more favorable than for those with non-AR-positive TNBC [8]. Several studies have sought to define the antitumor activity of AR inhibition in advanced TNBC. Gulcap et al. reported a six-month clinical benefit rate (CBR) of $19 \%(95 \% \mathrm{CI}=0.07-0.39)$ for the AR antagonist bicalutamide among 50 patients (12\% of 424 screened) with metastatic AR-positive TNBC [52]. The potent AR inhibitor enzalutamide was evaluated in 118 patients with AR-positive metastatic TNBC (55\% of 404 screened) [53]. Overall CBR at 16 weeks was $25 \%(95 \% \mathrm{CI}=0.17-0.33)$ and was $33 \%(95 \% \mathrm{CI}=$ $0.23-0.45$ ) among those whose tumors expressed $\geq 10 \%$ nuclear AR. Although this remains a treatment strategy of unknown importance, it is clear that optimizing a robust biomarker and/or signature for those most likely to respond to AR inhibition will be the key to pursuing it. Moreover, the inherently favorable biology of AR-positive advanced TNBC may also play a role in the apparent benefit from AR inhibition.

\subsection{Immune Checkpoint Molecule Inhibitor}

Immunologic escape describes the stage at which malignant clones acquire the capability of evading the adaptive immune system. Programmed cell death 1 (PD-1) is a transmembrane protein expressed on T cells, B cells, and NK cells: PD-1 ligand (PD-L1) binds to PD-1 and then directly inhibits apoptosis of the tumor cell while promoting peripheral $\mathrm{T}$ effector cell exhaustion and conversion of T effector cells to Treg cells [54]. In addition, PD-L1 is expressed on the surface of multiple tissue types, including many tumor cells, hematopoietic cells, and PD-1 ligand 2 (PD-L2) restricted hematopoietic cells. Tumors can upregulate the expression of PD-1 and PD-L1, which promotes peripheral $\mathrm{T}$ cell exhaustion [55]. Evidence that this approach may be useful in early breast cancer comes from a small neoadjuvant trial that discovered improved $\mathrm{pCR}$ when the anti-PD-1 antibody pembrolizumab was added to anthracycline/taxane-based chemotherapy [56]. Early clinical experience with immunotherapy for TNBC also includes small studies of the single-agent anti-PD-1 antibody pembrolizumab as well as anti-PD-L1 antibodies avelumab and atezolizumab, with response rates generally lower than 20\%, even in PD-L1-selected tumors [57,58]. In a phase III randomized trial (IMpassion 130 trial), 902 patients who had not received treatment for metastatic TNBC were randomly assigned to receive nab-paclitaxel with either atezolizumab or a placebo [59]. Overall, there was only a modest but statistically significant difference in PFS (7.2 vs. 5.5 months; $\mathrm{HR} 0.80,95 \% \mathrm{CI}=0.69-0.92)$ in favor of incorporating atezolizumab. However, in a prospectively planned subset analysis of outcomes according to PD-L1-expressing immune effector cells within the tumors, atezolizumab improved both PFS (7.5 vs. 5.0 months; HR 0.62, 95\% CI = 0.49-0.78) and, importantly, OS ( 25.0 vs. 15.5 months; HR $0.62,95 \% \mathrm{CI}=0.45-0.86$ ). Additional strategies, including combining immunotherapy with other systemic therapy or radiation, as well as other approaches, are currently in development (Figure 1C and Table 1). Furthermore, the optimization of biomarkers predictive of response to immunotherapy is actively under investigation. 


\section{CSCs and Drug Resistance in TNBC}

\subsection{Expression of Cancer Stemness}

In recent decades, the theory of CSCs or cancer stemness has captured much attention and interest. It is thought that this theory has potential to revolutionize our understanding of the cellular and molecular events during cancer progression and how they contribute to drug resistance, tumor recurrence, and metastasis [60]. Among solid tumors, breast CSCs (BCSCs) were the first to be identified. An extremely small number of BCSCs were able to produce tumors in immune-deficient NOD/SCID mice [61]. Conventional cancer therapies against the majority of cancer cells are insufficient to eradicate all cells within the tumor, especially CSCs, due to their highly resistant nature, leading to tumor recurrence and distant metastasis [62]. Two types of CSCs with resistant ability need to be addressed: quiescent (non-proliferative) CSCs and proliferative CSCs. These cell types express stemness properties, resistant features, metastasis and immune evasion, but could be discriminated from rate of cell cycle [63]. However, the consequence of quiescent CSCs for anti-mitotic chemodrugs treatment is different from proliferative CSCs. The proliferative CSCs would be killed by anti-mitotic agent with higher dosage than general tumor cells, but quiescent CSCs are still surviving in the highly dosage level. Indeed, after initially chemotherapeutic treatment, resident quiescent CSCs cause tumor relapse when they evoke by suitable niche signals [64]. Given dynamic cellular events during cancer progression and CSC-mediated resistance, understanding the heterogeneous nature of their regulatory mechanism provides a concrete foundation for the development of CSC-specific therapeutics.

In addition, another cell type, quiescent non-CSCs, also resists anti-mitotic drugs. In primary tumor, growth phases transition between proliferation and dormancy in non-CSCs are determined by genetic and epigenetic alternations $[63,65]$. Drug resistance remains a continuing challenge in cancer treatment and is undoubtedly the major reason for treatment failure [66,67]. Multidrug resistance (MDR) is a phenomenon that describes common clinical drug resistance to a broad spectrum of drugs [68,69]. For the proliferative CSCs, two types of drug resistance have been discussed: (1) acquired resistance in response to treatment and (2) intrinsic resistance, where resistance is to a spectrum of drugs, even when the drug is freshly used against a specific tumor $[67,70]$.

The concept of cancer stemness or CSCs is currently used to explain the mechanism of MDR. These cells are recognized as a group of cells that possess much higher endogenous resistance against radiation and chemotherapy than non-CSC differentiated tumor cells [71]. CSCs and normal stem cells (SCs) seem to share similar drug resistance abilities [72]. Because the pool of cells in an organism are maintained by SCs, it is necessary to maintain and protect these SCs biologically. Thus, several mechanisms have been developed to maintain cell stemness and avoid death by apoptosis. CSCs appear to apply these intrinsic "gadgets" against anticancer therapies. As a result, chemotherapy and radiotherapy treatment eradicate the majority of the population of non-CSCs but not CSCs, consequently leading to recurrence of the disease [73].

The study of CD44/CD24 and ALDH1 expression could be the most appropriate to identify BCSCs with distinct levels of differentiation from breast cancer populations. In an analysis of 466 invasive breast carcinomas and eight breast cancer cell lines, basal-like breast cancer harbored the highest percentage of tumor cells with the CSC phenotype $\mathrm{CD} 44^{+} \mathrm{CD} 24^{-/ \mathrm{low}}$ and ALDH1 positivity [74]. Clinically, their expression is associated with worse chemotherapy response, lymph node metastasis, distant metastasis, recurrence, and worse disease-free survival (DFS) and OS [75,76]. Enriched ALDH1-expressing cells are an independent prognostic factor that predicts poor prognosis in patients with TNBC [77-79]. Furthermore, the expression of STAT3 acts as a promising chemoresistance biomarker and is also associated with the $\mathrm{CD} 44^{+} / \mathrm{CD} 24^{-/ \mathrm{low}} / \mathrm{ALDH}^{+}$BCSC-like subset of the TNBC cell line [80]. In patients with TNBC, front-line chemotherapy effectively suppresses the bulk of primary tumors by eradicating proliferating cells but commonly fails to target the slow-cycling CSCs. Thus, identifying molecular drivers and signaling pathways that govern the self-renewal and expansion of CSCs has the potential to 
inspire new treatment options for this lethal disease. We herein discuss several mechanisms of MDR in TNBC against concurrent chemo regimens such as anthracyclines, taxanes, and/or platinum $[5,26,27]$.

\subsection{Cancer Niche and Therapy Resistance}

CSCs are located in a specialized microenvironment termed the niche that is mainly composed of cancer-associated fibroblasts (CAF), endothelial cells (ECs), mesenchymal SCs (MSC), tumor-associated macrophages (TAM), and extracellular matrix (ECM), which play different roles in orchestrating therapy resistance [81-83]. Secretion of several cytokines and chemokines, such as IL6/IL8, CXCL12, and CXCL7, in CSC niches activate the CSC signaling network and the NF- $\mathrm{kB}$ pathway, leading to CSCs characteristics and furthering therapy resistance [72]. Studies have demonstrated that CAF coculture increases the secretion of type I collagen, contributing to decreased drug uptake in breast cancer cell lines $[84,85]$. In addition, interaction between CAF and immune cells induces self-renewal properties through activation of NF-кB signaling in breast, gastric, prostate, and glioma CSCs [86]. CAF are able to secret exosomes through the receptor RIG-1 and activate STAT1 in breast cancer cells; in turn, STAT1 activation further activates NOTCH3, leading to increased drug resistance in CSCs [87]. MSCs are adult SCs that under normal conditions act as immunomodulators. However, similar to CAF, physical interaction between MSCs and breast cancer enhances resistance to trastuzumab through activation of the non-receptor tyrosine kinase Src and its downstream PI3K/Akt pathway [83]. Additionally, the interaction with MSCs mediates the acquisition of MDR proteins and also increases the resistance of epithelial ovarian cancers to carboplatin and paclitaxel [88]. The vascular microenvironment has been related to the maintenance of a self-renewing CSC pool in brain tumors since 2007 [89]. ECs secrete $\mathrm{TNF} \alpha$, which activates the NF- $\mathrm{B}$ signaling pathway in CSCs and induces the secretion of several factors, including CXCL1/2 in breast cancer; the process works through the attraction of immune cells and production of chemokines, including S100A8/9, which consequently induces chemoresistance to doxorubicin and cyclophosphamide. Furthermore, the resistance can be suppressed by CXCR2 blockers [90]. Immune cells such as TAMs interact with cancer cells through a variety of growth factors, cytokines, and chemokines [91,92]. For example, IL6 and STAT3 pathways are related to trastuzumab resistance in BCSCs [93]. The ECM is an assembly of molecules mostly secreted by fibroblasts. Increased ECM stiffness in solid tumors protects CSCs from chemotherapeutic agents resulting from physical barriers that separate the cells from any chemotherapeutic effect [94]. Moreover, the ECM interacts with CSCs, and regulates stem and proliferative signaling pathways as well as drug resistance. For example, hyaluronic acid is the ligand of the CD44 receptor, which mediates the acquisition and maintenance of CSCs upon interaction [95]. Tenascin C, which is expressed in ECM, improves the efficacy of the Wnt and Notch signaling pathways, thereby stabilizing BCSCs [96].

\subsection{Cell Membrane Transporters: ABC Family}

The ATP-binding cassette (ABC) transporters belong to a family of 49 membrane proteins usually related to the efflux of small molecules and compounds from the cytosol to the extracellular medium using ATP hydrolysis. Due to their ability to expel toxic chemicals, they participate in the development of MDR [97,98]. Many of the human ABC proteins are efflux transporters, and three of them, namely P-glycoprotein (P-gp/MDR1, gene symbol ABCB1), the multidrug resistance protein 1 (MRP1, gene symbol $A B C C 1$ ), and the breast cancer resistance protein (BCRP, gene symbol $A B C G 2)$, have been implicated as major efflux transporters responsible for multidrug resistance in cancer cells [99]. Many ABC transporters are expressed on the surface of CSCs [100]. Thus, staining a population of cells with Hoechst 33342 dye and Rhodamine 123 dye could identify CSC subpopulations within a tumor: This method of identification is due to these dyes being pumped out of CSCs, which can then be identified as the unstained subpopulation-so-called side population (SP) cells-in flow cytometry [101-103]. Notably, promoters of ABC transporters carry several binding sites for EMT-inducing transcription factors [104]. In breast cancer, one study reported a correlation between $A B C G 2$ mRNA expression and response in a subgroup of patients receiving anthracycline-based 
chemotherapy (5-fluorouracil, adriamycin/epirubicin, and cyclophosphamide), and such a correlation did not exist in the cyclophosphamide, methotrexate, and 5-fluorouracil-treated group of patients [105]. A search of the "GEO Profiles database" revealed a functional genomic aberration of $A B C B 1$ genes in five paclitaxel-resistant TNBC cell lines (data accessible at NCBI GEO database, accession No. GSE90564). Furthermore, a link between ABCB1 and the Hedgehog pathway supports the relationship between CSCs and ABC transporters [106].

\subsection{Epithelial-mesenchymal Transition (EMT)}

The mechanisms responsible for EMT and CSC-related drug resistance remain uncertain in most cases. One hypothesis suggests that cells undergoing EMT enter into a quiescent state and no longer divide [107]; however, most conventional treatments target actively dividing cells [72]. For example, in oral cancer cells, a SNAIL-mediated EMT phenotype exhibited quiescence and further induced resistance to chemotherapeutics [108]. Similarly, overexpression of TWIST, SNAIL, and the FOXC2-mediated EMT phenotype in TNBC cells led to MDR by upregulating ABC transporters [104]. In summary, EMT activation also promotes stemness and quiescence, which induce drug resistance in multiple cancers.

\subsection{Hypoxia and ROS}

The hypoxic niche plays an important role in the maintenance of SC characteristics during embryonic development and self-renewal $[109,110]$. In fact, CSCs are typically situated near hypoxic areas within tumors [111]. Hypoxia-inducible factor- $1 \alpha$ (HIF-1 $\alpha)$ is the main regulator of cellular responses to hypoxia. It is ubiquitinated at high oxygen levels and subsequently degraded. At decreased oxygen levels, HIF- $1 \alpha$ is activated upon ubiquitination inhibition, translocates into the nucleus, dimerizes with HIF-1 $\beta$, and activates the transcription of specific genes [112]. HIF- $1 \alpha$ has long been recognized as a pivotal orchestrator of cancer cell response to hypoxic microenvironments by regulating the expression of over 60 genes involved in metabolic reprogramming and $\mathrm{pH}$ balance, cell proliferation/survival, apoptosis, angiogenesis, SC maintenance, matrix remodeling, metastasis, and resistance to radiotherapy and chemotherapy $[113,114]$. Exposure of TNBC cells to hypoxia has been shown to increase the percentage of BCSCs in a HIF- $1 \alpha$-dependent manner $[115,116]$, which also contributes to multiple steps in the metastasis of TNBCs [117]. Clinically, in patients with breast cancer, HIF-1 $\alpha$ overexpression identified by immunohistochemistry of tumor biopsies has been associated with increased mortality [118]. Increased expression of hypoxia-induced genes in breast cancer is also associated with poor prognosis [119]. Furthermore, HIF-1 $\alpha$ expression has been reported to be correlated with MDR in breast cancers. For example, expression can be induced by treatment of breast cancer cells with doxorubicin under normoxic environments [120]. Further study revealed that in paclitaxel- or gemcitabine-treated TNBCs, the induction of HIF activity is required for enrichment of BCSCs both in vitro and in vivo [121]. Through the activation of HIF- $1 \alpha$, the expression of EMT and stemness activators such as WNT, Hedgehog, and NOTCH pathways, as well as other stemness markers such as FOXA2, cMET, CD133, NANOG, SOX2, SOX17, and PDX1 occurs [122,123]. Because hypoxia results in an unfavorable condition for cellular growth, it induces quiescence in cancer cells [124,125]. Under normal conditions, reactive oxygen species (ROS) accumulation leads to apoptosis in both normal and cancer cells $[126,127]$, whereas the HIF- $1 \alpha$ signaling pathway decreases the production of ROS and preserves SC properties leading to drug resistance in CSCs [72,128]. In mammospheres composed almost entirely of stem cells, suppressed levels of ROS were observed; this explains the higher rate of radioresistance when compared with differentiated adherent cells [129,130].

Aldehyde dehydrogenase (ALDH) is another molecule responsible for ROS decrease and is also a CSC marker [131]. It comprises a family of 19 cytosolic enzymes involved in intracellular aldehyde oxidation and in the oxidation of retinol to retinoic acid during the early stages of SC differentiation [132,133]. ALDH1, the main isoform, directly reduces ROS and produces antioxidant compounds such as NADP that further facilitates detoxification. In hematopoietic malignancies, 
ALDH expression is high in quiescent cells [134-136]. In addition, ALDH-positive tumors in cancers of the colon, breast, lung, pancreas, bladder, prostate, and ovary are tumorigenic and resistant to chemotherapy [134]. Further, ALDH1 also protects cells against alkylating agents such as paclitaxel [137]. Clinically, more than half of TNBC cases exhibit ALDH1 expression. The enriched ALDH1-expressing cells are an independent prognostic factor that predicts poor prognosis in patients with TNBC [77-79]. For the 234 patients treated with neoadjuvant chemotherapy, the $\mathrm{pCR}$ rate was significantly lower in ALDH1 $(+)$ cases $(13.5 \%$ vs. $30.3 \%, p=0.003)$. The $\mathrm{pCR}$ rate and ALDH1 expression were significantly correlated in patients with TNBC $(p=0.003)$. ALDH1 $(+)$ breast cancers tend to be aggressive with poor prognoses [138].

\subsection{High Survival Capacity of CSCs}

CSCs are multipotent SCs responsible for the long-term clonal maintenance and growth of most human neoplasms. They can coexist in a cycling and quiescent state as they acquire mutations that further increase heterogeneity [139]. CSCs of the lung, pancreas, glioma, and breast possess highly active DDR systems [71,130]. In CD $44^{+}$CD $24^{-/ \text {low }}$ BCSCs, DNA single-strand break repair is particularly active and linked to APE1 upregulation [140]. In addition to DNA repair systems, studies have suggested that the mutation or inactivation of cell cycle-regulating genes and apoptosis-inducing genes help CSCs to escape apoptosis [141]. The most well-known example, the loss of p53 function in colon, breast, and lung carcinoma, promotes SNAIL-mediated EMT expression, resulting in increased radioresistance [141]. Compared with their relatively more differentiated counterparts, BCSCs exhibit reduced levels of oxidative DNA damage, both at baseline and after irradiation [130]. EZH2 participates in histone methylation and is also involved in the expansion of $\mathrm{CD} 44^{+} \mathrm{CD} 24^{-/ \mathrm{low}}$ BCSCs by epigenetically repressing DNA repair [142]. The basal activation status of checkpoint kinases (rather than the hyperactivation of DNA repair) may also constitute a key mechanism by which CSCs resist genotoxic agents. In studies of human breast tumors, the EMT-inducing transcription factor ZEB1promotes expression of CHK1, which is required to mediate the ATM-dependent $\mathrm{G}_{2}-\mathrm{M}$ checkpoint to survive radiotherapy and eventual metastatic relapse. This result was further established following the inhibition of CHK1, which resensitized the cells [143]. Furthermore, the abrogation of AKT1 signaling increases the radiosensitivity of BCSCs by inhibiting WNT signaling [144]. Collectively, multiple processes have been targeted to force differentiation or reduce DDR signaling and thus increase CSC sensitivity to DNA damage. These results indicate that DDR also stands out as a promising therapeutic target for BCSC eradication.

\section{Potential Targeting Strategies against CSCs in TNBC}

Several clinical trials have been designed that combine conventional chemotherapy and adjuvant therapies in the hope of eliminating both actively dividing cells and CSCs. These CSC-targeted adjuvant regimens may either attack stem-related pathways or enhance the drug sensitivity of CSCs in distinguished ways (Table 2). In the following, we present intriguing preclinical results that describe many therapeutic strategies that specifically target BCSCs. 
Table 2. The ongoing clinical trials of potential targeting molecules in carcinoma diseases.

\begin{tabular}{|c|c|c|c|c|c|c|}
\hline Target & Major Drug & $\begin{array}{l}\text { Combinational } \\
\text { Drug }\end{array}$ & Indication & Phase & $\begin{array}{l}\text { NCT } \\
\text { Identifiers }\end{array}$ & Status \# \\
\hline \multicolumn{7}{|l|}{ Receptor } \\
\hline \multirow{9}{*}{ IGF-1R } & \multirow{3}{*}{$\begin{array}{l}\text { AMG479 } \\
\text { (Ganitumab) }\end{array}$} & \pm Dasatinb & $\begin{array}{l}\text { Embryonal and } \\
\text { alveolar } \\
\text { rhabdomyo-sarcoma }\end{array}$ & $\mathrm{I} / \mathrm{II}$ & NCT-03041701 & $\mathrm{R}$ \\
\hline & & $\begin{array}{l} \pm(\text { Everolimus }+ \\
\text { Panitumumab) }\end{array}$ & $\begin{array}{l}\text { Advanced solid } \\
\text { tumors, NSCLC }\end{array}$ & I & NCT-01061788 & $\mathrm{Ac} / \mathrm{NR}$ \\
\hline & & $\begin{array}{l} \pm \text { Vincristine }+ \\
\text { Doxorubicin }+ \\
\text { Cyclo-phosphamide } \\
\text { / Ifosfamide }+ \\
\text { Etoposide }\end{array}$ & $\begin{array}{l}\text { Metastatic } \\
\text { malignant } \\
\text { neoplasm in the } \\
\text { bone, bone } \\
\text { marrow, lung, and } \\
\text { etc. }\end{array}$ & III & NCT-02306161 & $\mathrm{Ac} / \mathrm{NR}$ \\
\hline & \multirow{2}{*}{ Cixutumumab } & $\begin{array}{l} \pm \text { Lapatinib } \\
\text { ditosylate }+ \\
\text { Capecitabine }\end{array}$ & Breast cancer & II & NCT-00684983 & $\mathrm{Ac} / \mathrm{NR}$ \\
\hline & & \pm Paclitaxel & $\begin{array}{l}\text { Esophageal cancer, } \\
\text { Gastro-esophageal } \\
\text { junction } \\
\text { adeno-carcinoma }\end{array}$ & II & NCT-01142388 & $\mathrm{Ac} / \mathrm{NR}$ \\
\hline & $\begin{array}{l}\text { DNA Plasmid } \\
\text { Based Vaccine } \\
\text { (WOKVAC) }\end{array}$ & - & Breast cancer & I & NCT-02780401 & $\mathrm{R}$ \\
\hline & $\begin{array}{l}\text { MK-0646 } \\
\text { (Dalotuzumab) }\end{array}$ & $\begin{array}{l} \pm \text { Gemcitabine + } \\
\text { Erlotinib }\end{array}$ & $\begin{array}{l}\text { Advanced } \\
\text { pancreatic cancer }\end{array}$ & $\mathrm{I} / \mathrm{II}$ & NCT-00769483 & $\mathrm{Ac} / \mathrm{NR}$ \\
\hline & Teprotumumab & - & $\begin{array}{l}\text { Thyroid eye } \\
\text { disease, Graves' } \\
\text { orbitopathy }\end{array}$ & III & NCT-03298867 & Ac/NR \\
\hline & Trastuzumab & $\begin{array}{l} \pm \text { Lapatinib } \\
\text { ditosylate }\end{array}$ & Breast cancer & III & NCT-01104571 & $\mathrm{Ac} / \mathrm{NR}$ \\
\hline nAChR & Bupropion & - & Breast cancer & III & NCT-03996265 & $\mathrm{R}$ \\
\hline \multicolumn{7}{|l|}{ Cytokine } \\
\hline IL-6 receptor & Tocilizumab & $\begin{array}{l} \pm \text { Ipilimumab + } \\
\text { Nivolumab }\end{array}$ & $\begin{array}{l}\text { Advanced } \\
\text { melanoma }\end{array}$ & II & NCT-03999749 & $\mathrm{R}$ \\
\hline IL-7 receptor & Tocilizumab & $\begin{array}{l} \pm \text { Gemcitabine }+ \\
\text { nab-Paclitaxel }\end{array}$ & $\begin{array}{l}\text { Unresectable } \\
\text { pancreatic } \\
\text { carcinoma }\end{array}$ & II & NCT-02767557 & $\mathrm{R}$ \\
\hline \multicolumn{7}{|c|}{ Dormancy and proliferation } \\
\hline & $\begin{array}{l}\text { All-trans retinoic } \\
\text { acid (ATRA) }\end{array}$ & \pm 5-Azacitidine & Prostate cancer & II & NCT-03572387 & $\mathrm{R}$ \\
\hline \multicolumn{7}{|l|}{ Metabolism } \\
\hline $\begin{array}{l}\text { Glycolysis } \\
\text { inhibition }\end{array}$ & $\begin{array}{l}\text { 2-Deoxyglucose } \\
\text { (2DG) }\end{array}$ & - & $\begin{array}{l}\text { Advanced cancer } \\
\text { and hormone } \\
\text { refractory prostate } \\
\text { cancer }\end{array}$ & $\mathrm{I} / \mathrm{II}$ & NCT-00633087 & $\mathrm{T}$ \\
\hline \multicolumn{7}{|c|}{ Autophagy pathway } \\
\hline \multirow{3}{*}{$\begin{array}{l}\text { Autophagy } \\
\text { inhibition }\end{array}$} & Hydro-chloroquine & - & Breast cancer & II & NCT-01292408 & $\mathrm{U}$ \\
\hline & \multirow{2}{*}{ Chloroquine } & $\begin{array}{l} \pm \text { Carboplatin }+ \\
\text { Gemcitabine }\end{array}$ & $\begin{array}{l}\text { Advanced solid } \\
\text { tumors }\end{array}$ & I & NCT-02071537 & $\mathrm{R}$ \\
\hline & & $\begin{array}{l}\text { + Temozolomide + } \\
\text { Radiotherapy }\end{array}$ & $\begin{array}{l}\text { Glioblastoma } \\
\text { multiforme }\end{array}$ & I & NCT-02378532 & $\mathrm{R}$ \\
\hline
\end{tabular}


Table 2. Cont

\begin{tabular}{|c|c|c|c|c|c|c|}
\hline Target & Major Drug & $\begin{array}{l}\text { Combinational } \\
\text { Drug }\end{array}$ & Indication & Phase & $\begin{array}{l}\text { NCT } \\
\text { Identifiers }\end{array}$ & Status \# \\
\hline \multicolumn{7}{|c|}{ Drug resistance } \\
\hline \multirow{12}{*}{$\begin{array}{l}\text { Resistance } \\
\text { inhibition }\end{array}$} & \multirow{2}{*}{ Doxycycline } & - & $\begin{array}{l}\text { Bone-targeted } \\
\text { therapy in patients } \\
\text { with metastatic } \\
\text { breast cancer }\end{array}$ & II & NCT-01847976 & $\mathrm{U}$ \\
\hline & & - & $\begin{array}{l}\text { Cutaneous T-cell } \\
\text { lymphoma }\end{array}$ & II & NCT-02341209 & $\mathrm{R}$ \\
\hline & \multirow{10}{*}{ Metformin } & - & Colon cancer & II & NCT-03359681 & NR \\
\hline & & - & Prostate cancer & II & NCT-03137186 & $\mathrm{R}$ \\
\hline & & - & Prostate cancer & II & NCT-02176161 & $\mathrm{R}$ \\
\hline & & - & $\begin{array}{l}\text { Breast cancer } \\
\text { prevention }\end{array}$ & III & NCT-01905046 & $\mathrm{R}$ \\
\hline & & + Doxycycline & $\begin{array}{l}\text { Breast and uterine } \\
\text { corpus cancer }\end{array}$ & II & NCT-02874430 & $\mathrm{R}$ \\
\hline & & + Erlotinib & TNBC & I & NCT-01650506 & C \\
\hline & & $\begin{array}{l}\text { + Paclitaxel + } \\
\text { Carboplatin + } \\
\text { Docetaxel }\end{array}$ & $\begin{array}{l}\text { Ovarian, primary } \\
\text { peritoneal, or } \\
\text { fallopian tube } \\
\text { carcinoma }\end{array}$ & II & NCT-02122185 & $\mathrm{R}$ \\
\hline & & + Pembrolizumab & Melanoma & I & NCT-03311308 & $\mathrm{R}$ \\
\hline & & + Temozolomide & Glioblastoma & II & NCT-03243851 & \\
\hline & & + Temsirolimus & Advanced cancers & I & NCT-01529593 & $\mathrm{Ac} / \mathrm{NR}$ \\
\hline \multicolumn{7}{|l|}{ Others } \\
\hline CD44 & RO5429083 & - & $\begin{array}{l}\text { CD44-expressing, } \\
\text { malignant solid } \\
\text { tumors }\end{array}$ & I & NCT-01358903 & $\mathrm{C}$ \\
\hline ER & Tamoxifen & + 9-Cis-retinoic acid & Breast cancer & I & NCT-00001504 & C \\
\hline GD2 & 3F8/GM-CSF & $\begin{array}{l}+13 \text {-Cis-retinoic } \\
\text { acid }\end{array}$ & $\begin{array}{l}\text { Primary refractory } \\
\text { neuroblastoma in } \\
\text { bone marrow }\end{array}$ & II & NCT-01183897 & $\mathrm{Ac} / \mathrm{NR}$ \\
\hline \multirow[t]{2}{*}{ Hedgehog } & Vismodegib & - & $\begin{array}{l}\text { Basal cell } \\
\text { carcinoma }\end{array}$ & II & NCT-03035188 & $\mathrm{R}$ \\
\hline & & + RO4929097 & Breast cancer & I & NCT-01071564 & $\mathrm{T}$ \\
\hline
\end{tabular}

\#, R: recruiting; Ac/NR: active, not recruiting; T: terminated; U: unknown; C: completed; NR: not yet recruiting.

\section{Targeting CSCs}

\subsection{Targeting CSC Specific Marker}

Previous studies have revealed that increased cyclophosphamide sensitivity of lung cancer cells could be achieved by knockdown of two ALDH isoforms [145]. As previously mentioned, high levels of ALDH are expressed in CSCs, decreasing levels of ROS and protecting the cells from ROS-mediated DNA damage and subsequent apoptosis [146]; this indicates the potential of ALDH-targeting treatments. Another example is the targeted delivery of iron oxide nanoparticles to CD44 ${ }^{+}$cells for the selective killing of BCSCs using conventional chemotherapy [147].

\subsection{Targeting CSC Signaling}

Due to limited specific markers, several studies have tried to eliminate CSCs by targeting highly activated signaling pathways in these cells. A number of signaling pathways have been associated with the therapy-resistant phenotype of BCSCs, including Notch, Hedgehog, and Wnt, which regulate apoptosis escape, maintenance of a stem cell niche, and increased invasion capacity [148-150]. One example of a relatively favorable result concerns basal cell carcinoma; here, the Hedgehog pathway inhibitor, vismodegib, was used. In phase II clinical trials, vismodegib treatment improved one-year median survival in comparison with patients receiving a standard treatment [151,152]. Dasatinib 
is a potent, oral SRC-family kinase inhibitor with preclinical antiproliferative, antimetastatic, and antiosteoclastic activity in triple-negative or basal-like breast cancer cell lines. However, single-agent dasatinib has limited activity in unselected patients with TNBC. Thus, future studies should investigate repositioning dasatinib in other breast cancer settings, including chemotherapy combinations [153]. Recent in vitro studies have reported an induction of the Wnt pathway in a compensatory fashion when a TNBC cell line is challenged with pan-PI3K inhibition (buparlisib). Essentially, dual PI3K and Wnt pathway inhibitors work as a synergistic combination against cell viability and enhance antitumor efficacy in TNBC cell lines [154]. This approach suggests a paradigm in which targeting both pathways (genomically-aberrant and compensatory) can induce synergistic effects from inhibitors.

\subsection{Targeting CSC Dormancy and Proliferation}

Cancer cell dormancy is attributable to $\mathrm{G}_{0}$ cell cycle arrest at the single-cell level, which resembles CSCs in primary tumors [155]. The process can be achieved by activating quiescence signaling as a response to new signals in the niche or from the loss of dependent background signals-for instance, hypoxia [146]. To date, the mechanisms underlying local cancer cell dormancy remain largely unknown. Several pharmacological strategies have, therefore, been suggested (i) to maintain cancer cells in the dormant state, (ii) to reactivate dormant cells to increase their sensitivity to anti-proliferative drugs, and (iii) to eliminate dormant cancer cells [155]. The concept of maintaining cancer dormancy first emerged from hormone-deprivation therapy in hormone-dependent cancers; for example, ER+ breast cancer. Today, standard adjuvant anti-estrogen therapy with tamoxifen or the aromatase inhibitor letrozole have been shown to suppress outgrowth of dormant cancer cells and to improve the survival of patients with breast cancer [156,157]. Similarly, dormancy of disseminated breast cancer was able to be maintained with the ERK inhibitor U0126 or the Src inhibitor PP1 [158]. Inhibitors of CDK4/6, which mediate the transition from the $\mathrm{G}_{0} / \mathrm{G}_{1}$ phase to the S-phase of the cell cycle, induce reversible or irreversible $\mathrm{G}_{0} / \mathrm{G}_{1}$ cell cycle arrest in various cancer models [159,160]. Currently, several clinical trials of CDK4/6 inhibitors have been conducted in TNBC (Figure 1B and Table 1). In addition, administering the factors of the premetastatic dormant niche, such as GAS6, BMP4, and BMP7, as well as TGF- $\beta 2$ [161-163], has been shown to maintain dormancy in disseminated tumor cells (Figure 2). Most recently, Puig et al. demonstrated that upregulation of the epigenetic modification enzyme TET2 and its catalytic product $5 \mathrm{hmC}$ are biomarkers of slow-cycling cancer cell, a cell in dormancy state with chemoresistance, in different cancer types. Targeting TET2 would reverse dormant cell to proliferative cell and diminish chemoresistance [65]. An awakening strategy that forces the cell cycle to operate has been proposed to improve the sensitivity of antiproliferative drugs. In the example of hematopoietic malignancies, apoptotic death of leukemic promyelocytes was achieved by all-trans retinoic acid (ATRA), which induced terminal differentiation [164]. Similarly, Yan et al. demonstrated in breast cancer that ATRA treatment resensitized MDR MCF-7 to epirubicin treatment [165]. In addition, osteopontin is produced by osteoblasts to maintain quiescence in leukemia cells. Neutralization forces dormant leukemia cells to reenter the cell cycle and, crucially, synergistically reduce residual disease in combination with cytarabine chemotherapy [166]. Similarly, treatment with IFN $\alpha$ induces proliferation of dormant hematopoietic SCs, sensitizing them to chemotherapy with 5-fluorouracil [167]. Lastly, an important strategy is to develop drugs that directly kill the dormant cells. For example, in a pancreatic ductal adenocarcinoma model, IGF-1R tyrosine kinase inhibitor, linsitinib, eliminated residual dormant cancer cells with ablation of K-RAS or c-MYC oncogenes [168]. In addition, hydrochloroquine, an autophagy inhibitor, impaired the survival of dormant breast cancer cells, demonstrating a modest effect on metastatic growth [169]. Interestingly, a time sequential treatment of these drugs rather than cotreatment exhibited superior benefit [170-172]. For example, Src inhibitors targeting dormant cancer cells improved the efficacy of docetaxel in breast cancer only when administered as a posttaxane treatment but not when the two drugs were administered simultaneously [173]. In summary, targeting dormant CSCs may be a potentially promising strategy; however, its effectiveness remains largely 
undetermined. Given that no available diagnostic tools for dormant cell detection currently exist, it remains impossible to evaluate the efficacy of this dormant cell-killing approach in patients.

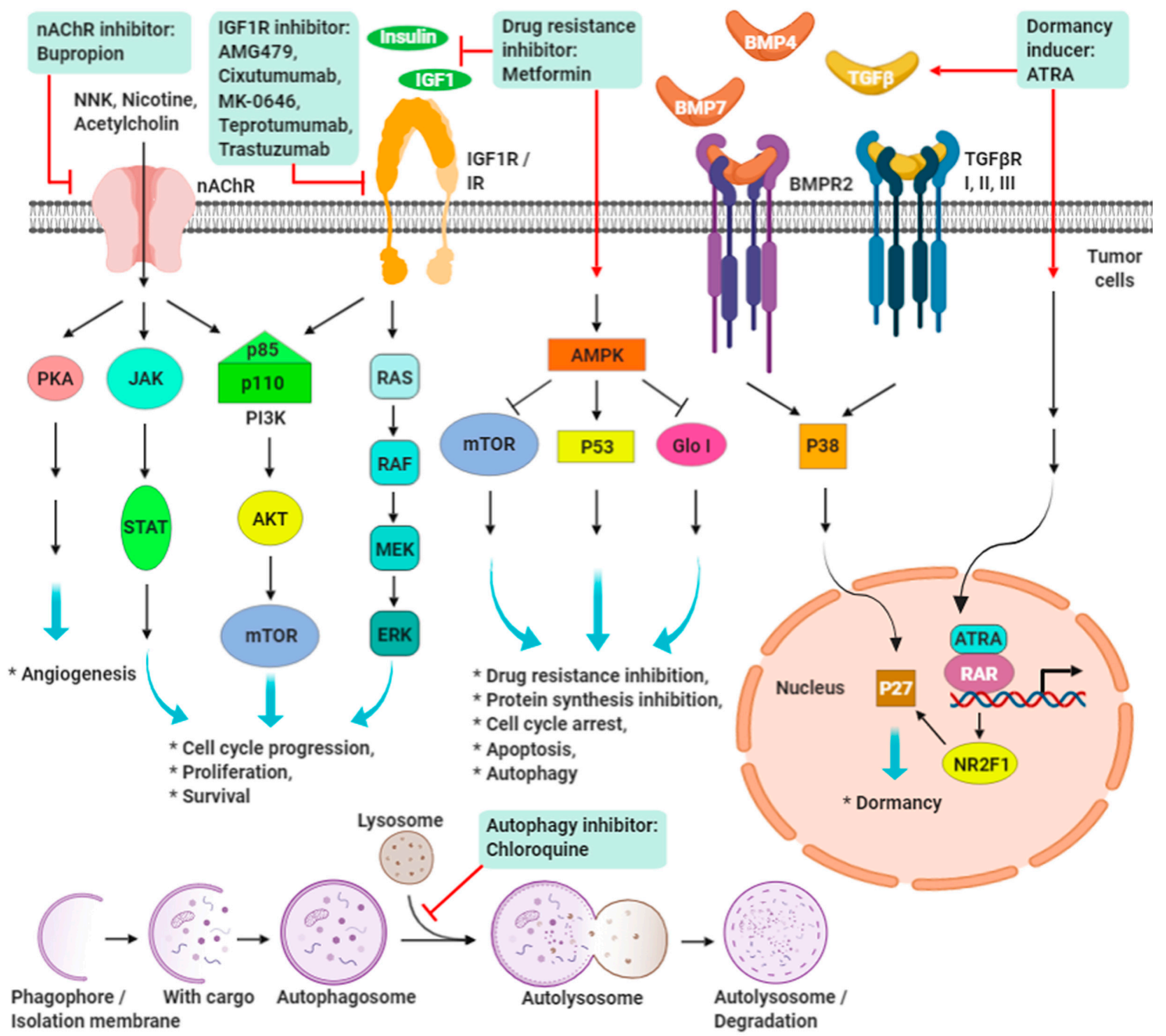

Figure 2. Diagram of ongoing clinical trials of potential targeting strategies against CSCs in carcinoma. System view of signaling pathways activated by extracellular stimuli, which triggered multiple biological functions through subsequent effectors. Numerous inhibitors and inducer attempt to attack either these critical molecules or pathways in CSCs in several types of carcinoma.

\subsection{Targeting CSC Metabolism}

The Warburg effect of aerobic glycolysis describes rapidly proliferating cancer cells that overtake angiogenesis, resulting in areas of low oxygen that accelerate glycolytic production of ATP [174]. However, increasing evidence suggests that cancer cells engage in glycolysis even in the presence of oxygen $[175,176]$. In contrast to normal SCs, which rely heavily on oxidative phosphorylation (OXPHOS) as their primary source of energy, CSCs exhibit unique metabolic flexibility, which primarily entails glycolysis, and can switch between the two in the absence or presence of oxygen to maintain homeostasis; this can promote tumor growth and eventually metastasis [175,177-181]. This observation is supported by studies that have demonstrated that BCSCs consume more glucose, produce less lactate, and have higher ATP content compared with their differentiated progeny [182], providing hints of a possible CSC metabolism-targeted strategy. To date, the inhibition of glycolysis can be achieved by targeting various glycolytic enzymes, transporters, and other complex regulators, such as GLUT1-4, hexokinase, PKM2, and lactate dehydrogenase A [183-185]. For instance, the proglyolytic phenotype of BCSCs is associated with decreased expression and activity of pyruvate dehydrogenase 
(Pdh), a key regulator of OXPHOS; meanwhile, metabolic reprogramming through forced activation of Pdh preferentially eliminates BCSCs both in vitro and in vivo [186]. Moreover, treatment with 2-deoxyglucose, a well-known inhibitor of glycolysis, inhibits BCSC proliferation when used alone and demonstrates a synergic effect when used in combination with doxorubicin [187]. SC markers, such as NANOG, have been implicated in various cancers and have been found to repress mitochondrial OXPHOS genes and ROS generation as well as activate fatty acid oxidation to support CSC self-renewal and drug resistance (Figure 3); however, the restoration of OXPHOS activity and inhibition of fatty acid oxidation renders CSCs susceptible to a standard care chemotherapy drug for hepatocellular carcinoma (HCC), sorafenib [188]. The BCSC marker CD44 interacts with PKM2, enhancing the glycolytic profile of cancer cells deficient in p53 or exposed to hypoxia. Subsequent ablation of CD44 led to the inhibition of glycolysis, an increase in ROS, and the enhancement of chemotherapeutic drug effect in these cancer cells $[189,190]$. In addition to supporting metabolic plasticity, simultaneous enhancement of glycolysis and OXPHOS pathways was observed in highly metastatic breast cancer cell lines relative to nonmetastatic cell lines [181,191]. Thus, inhibition of glycolytic and/or mitochondrial energy pathways has proven to be effective against tumor growth in a number of preclinical cancer models [187]. Taken together, targeting the CSC metabolism offers considerable potential for developing improved treatments to eradicate them.

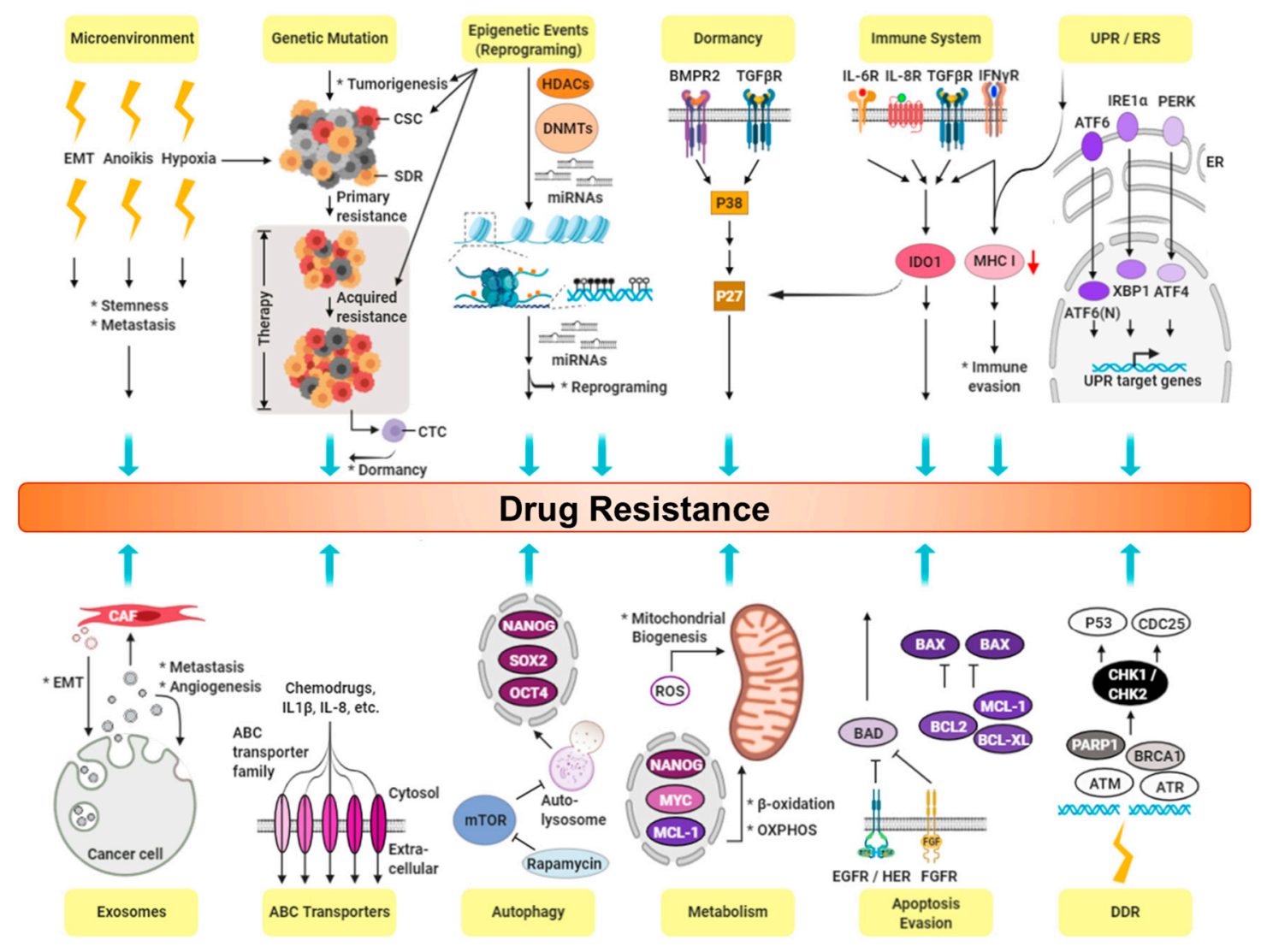

Figure 3. Diagram of molecular pathways involving in CSC drug resistance. System view of drug resistance, which triggered by multiple pathways through subsequent effectors. Some effectors can cross-talk to other molecules leading to stimulate different biological functions, which cooperatively play roles in drug resistance in CSCs. EMT: epithelial-mesenchymal transition; SDR: spontaneous drug resistance; CTC: circulating tumor cell; UPR: unfolded protein response; ERS: endoplasmic reticulum stress; DDR: DNA damage response; ROS: reactive oxygen species; CAF: cancer-associated fibroblast. 


\subsection{Targeting CSC Autophagy}

Autophagy homeostasis has been strongly associated with CSC physiology, such as tumorigenesis, differentiation, plasticity, migration/invasion, and pharmacological, viral and immune-resistance [192]. Currently, evidence from breast [193,194], pancreatic, liver [195], osteosarcoma [196], ovarian [197], and glioblastoma [198] CSCs has linked it to autophagy and demonstrated that its suppression negatively affects cell self-renewal capacity. Two key autophagy proteins, BECLIN1 and ATG4, are upregulated in mammospheres when compared to adherent cells, and they are needed for their maintenance and expansion $[199,200]$. Autophagy has demonstrated the ability to regulate $\mathrm{ALDH}^{+}$ BCSCs tumorigenicity through EGFR/STAT3 signaling in a mouse model [201]. Furthermore, recent findings suggest crosstalk between autophagy and EMT [202], chromosome stability [203], cytokines mediation [204], and SC microenvironments [205] in a variety of CSC regulations. Several experimental approaches have revealed that combining cytotoxic drugs and autophagy inhibitors increases CSC sensitivity [206]. For example, chloroquine (a late-stage autophagy inhibitor) enhances drug cytotoxicity in glioblastoma CSCs and reduces their survival when used in combination with EGFR inhibitors or temozolomide $[207,208]$. Similarly, inhibition of autophagy by chloroquine impairs cell migration and invasion, increases expression of the epithelial marker CD24, and decreases vimentin in BCSCs [208]. Other reagents associated with autophagy-mediated stemness also act in a similar manner. For example, resveratrol-induced autophagy acts on BCSC survival by inhibiting the Wnt pathway [209]. In summary, uncovering the contribution of autophagy to CSC drug resistance remains critical for the development of novel antineoplastic therapies.

\subsection{Reducing CSC Resistance}

Metformin, the most well-known medication for type II diabetes, is a candidate for reducing CSC resistance $[210,211]$. It has been shown to suppress the BCSC subpopulation, partly through ABC transporter inhibition [211,212]. In addition, Shi et al. investigated the use of metformin target KLF5 for degrading and preventing the activation of KLF5 downstream target genes NANOG and FGF-BP1, which consequently reduced the subpopulation of BCSCs in TNBC [213]. Currently, metformin is used in clinical trials as an adjuvant therapy [214]. Doxycycline, an FDA-approved antibiotic, has been found to reduce bone metastasis and tumor burden in breast and pancreatic cancers $[215,216]$. Doxycycline was able to reduce CSC resistance to Paclitaxel through the inhibition of mitochondrial biogenesis [217]. Currently, clinical studies are being conducted in advanced breast cancer [NCT01847976].

\subsection{Targeting CSC-related Niche}

The CSC niche regulates intrinsic resistance (Figure 3). Therefore, apart from directly targeting CSCs, instantaneously attacking the CSC microenvironment could be another compelling strategy. Studies have demonstrated that non-CSCs can be reprogrammed to CSCs using EMT [125]. By targeting CAFs and TAMs that secrete EMT-inducing factors, blockage of EMT could be accomplished [91,218]. CAFs play a critical role in the tumor niche, where CSCs maintain high tumorigenicity and cancer stemness with significantly high expression of OCT4 and NANOG. Furthermore, differentiated tumor cells can dedifferentiate into CSCs by being cocultured with CAFs, which suggests signaling crosstalk between CSCs and CAFs; indeed, a paracrine network of IGF/IGF-1R was found to contribute to cancer stemness in the niche environment [219]. IGF-1 is also an obvious serum marker for late-stage endometriosis [220]. Although endometriosis is a nonmalignant disorder, it presents high levels of OCT4 in endometriotic cells [221]. Reportedly, OCT4 is regulated by IGF-1 [110,222-224], which suggests that IGF-1 is a critical niche factor for disease progression to an advanced stage of endometriosis.

Evidence has shown chronic inflammation serves as a protumorigenic factor. High serum levels of IL6, an inflammatory cytokine, can predict the development of hepatitis B virus (HBV)-infected hepatocellular carcinoma (HBV-HCC) [225]. The niche of IL6 stimulates the expression of IGF-1R and autocrinal IGF1 dependently in HBV-HCCs and strongly correlates with OCT4/NANOG expression, 
early recurrence, and cancer stemness features. Blockage of IL6 and IGF-1R activation disrupts expression of cancer stemness properties in vitro and in vivo, indicating that the inflammatory niche of IL6 promotes early recurrence through IGF-1R activation in patients with HBV-HCC [223]. Furthermore, long-term use of anti-inflammatory anti-cyclooxygenase-2 (COX-2) contributes to 40-50\% risk reduction in colon cancer [226]. Some studies have also demonstrated that Celecoxib (COX-2 inhibitor) treatment reduces colorectal CSC subpopulations $[227,228]$. In addition, treating TNBC cells with IFN $\beta$ suppresses the CSC properties, resulting in decreased tumor sphere formation, EMT expression, and migration, thereby promoting an epithelial phenotype with reexpression of CD24 [229]. Studies have demonstrated the potential of targeting the ECM and its associated proteins. Enzymatic destruction of hyaluronic acid results in stroma reduction and vasculature reexpansion, allowing increased distribution of standard chemotherapy with benefits in an animal pancreatic cancer model [230], and thereby signifying that cancer cells or CSCs are not the only anticancer targets.

Nicotine is a component of tobacco and e-cigarettes, and its receptors (nicotinic acetylcholine receptors, $\mathrm{nAChRs)}$ are carcinogens contributing to various cancers. A previous study demonstrated that nicotine not only results in the upregulation of the stemness-related genes OCT4, SOX9, HES1, ALDH1, and STAT3 in pancreatic tumors but also promotes EMT behavior and metastasis [231]. In addition, nicotine also promotes expression of SOX2 and OCT4 through the $\alpha 7-\mathrm{nAChR} / \mathrm{YAP} 1 / \mathrm{E} 2 \mathrm{~F} 1$ axis in non-small-cell lung cancer (NSCLCs). Tumor cells acquire stemness functions to initiate self-renewal proliferation and migration in NSCLCs [232]. These results strongly support an important role for OCT4 in niche-mediated tumorigenesis and malignancy. Therefore, these molecules and signaling pathways could provide potential strategies for inhibiting nicotine-induced stemness properties and the proliferation of CSCs.

\section{Promising Targeting Strategies on IGF-1R and nAChRs in TNBC}

\subsection{IGF/IGF-1R Signaling}

The IGF signaling system controls energy metabolism, stem cell self-renewal, cell growth, and body size in normal physiology $[110,233,234]$. Our recent studies on embryonic germline stem cells have demonstrated that IGF1/IGF-1R coordinates hypoxia signals to induce OCT4 expression, maintain normal SC activity, and execute symmetric self-renewal proliferation through HIF-2 $\alpha$ [110,224]. Moreover, evidence in tumor biology suggests that the IGF signaling pathway is important for tumorigenesis and tumor cell survival and provides chemoresistance ability in several types of cancers, including cancers of the liver, lung, endometrium, prostate, colon, rectum, pancreas, and ovary [222,223,235-243]. Patients with breast cancer tend to exhibit high serum levels of IGF-1 [244], and activation of the IGF gene signature has been observed in triple-negative or basal-like breast cancer cell lines [245]. Chang et al. reported that IGF-1 signaling plays an important role in breast cancer progression by controlling both the maintenance of BCSCs and their EMT behavior [246]. Activation of IGF-1R-AKT signaling also elevates CSC properties in platinum-taxol resistant ovarian cancer cell lines [247]. Furthermore, our previous studies have demonstrated that highly expressed IGF-1R was observed in HBV-HCC tissues and was strongly associated with the early recurrence of tumors; furthermore, activation of IGF-1R signaling reduces the susceptibility of tumor cells to chemotherapies; both these outcomes result from induction of critical pluripotent markers, OCT4 and NANOG, by IGF-1R activation in HBV-HCC [222,223]. Therefore, IGF signaling remains a promising therapeutic target for CSCs and chemoresistant diseases.

\subsection{Nicotine/Nicotinic Acetylcholine Receptors Signaling}

Numerous studies have identified the distinguished nAChRs subtypes as mediating tobacco-related cancer development and progression. The $\mathrm{AAChRs}$ transduce various signaling cascades upon activation, which govern several pathological conditions, namely tumorigenesis [248-255], metastasis [250,256-260], drug resistance [249,261-263], and cancer stemness [263-266], during 
carcinogenesis. The homo-pentamer of the $\alpha 7$-nAChR subtype is associated with lung [250,255], bladder [253,261], colon [267-269], gastric [257,259], and pancreatic [258,262,264] cancer pathologies. In breast cancer cells, the $\alpha 9-\mathrm{nAChR}$ subtype is the most validated [252]. Studies have identified that $\alpha 9-\mathrm{nAChR}$ has a role in tumor carcinogenesis in vivo and nicotine-induced transformation of normal human breast epithelial cells in vitro [248,252,270,271]. Moreover, a signaling cascade involving galectin-3, $\alpha 9-\mathrm{nAChR}$, and STAT3 regulated the enrichment of side population cells with CSC-like properties [263]. Therefore, exposure to nicotine has been correlated with CSC regulation [263-266]. Most recently, our work on membrane protein communities and cancer membrane protein-regulated networks discovered 13 new interaction proteins (e.g., ERBB2) with $\alpha 9$-nAChR across human cancers [272]. In addition, further experiment has revealed that the FDA-approved drug bupropion, which targets $\alpha 9$-nAChR, acts as an antimetastasis agent in nicotine-induced breast cancer. In summary, these results indicate the crucial role of $\alpha 9-\mathrm{nAChR}$ in the identification of biomarkers and therapeutic targets and agents.

\section{Precision Treatment of TNBC}

In addition to molecular approach, there are several functional profiling approaches to establish precision treatment strategies against TNBC. Heiser et al. have studied that the variant responses to 77 therapeutic compounds are occurred across numerous breast cancer cell lines including TNBC subtype, and approximately one third showing these specific responses depend on subtype, pathway, and/or genomic aberration [273]. Since last decade, several molecular profiles with measurements of the omics and biological therapeutic responses have enabled the identification of distinctive features that can predict therapeutic response [274,275]. Notably, therapeutic responses are regulated at multiple levels in the genome of different individuals. Based on the patient's transcriptional subtype, the response rates of precision treatments could be improved [276]. The so-called functional subtyping of breast cancer allows the screening of clinical significance from the wealth of molecular profiling data, speeding the emergence of personalized therapeutic regimens. Extending the work to TNBC, Gautam et al. have studied the responses of 301 approved and investigational oncology compound in 16 TNBC cell lines applying a functional profiling approach. This work revealed that certain levels of protein markers associated with cytotoxic response might serve as markers of response in clinical settings [277]. Furthermore, by utilizing a multiplexed readout for both cell viability and cytotoxicity, a defined spectrum of cellular responses both to single agents and novel combinations in TNBC has been identified. Moreover, the advancement of machine learning for efficient identification of breast cancer-selective therapeutic targets could be the next step for identifying precision medicine approaches in the future [278]. Taken together, systems biology and omics strategies for matching patient cohorts could efficiently respond to new therapies in TNBC, as well as in other types of cancers.

\section{Conclusions}

In this review, we pointed out how multiple mechanisms underlying CSC maintenance give rise to not only tumor survival but also plasticity to drug resistance, particularly under unfavorable stress (Figures 1-3). Current clinical practice and ongoing trials on TNBC were discussed systemically, including targeted therapy and subtype-based therapeutic strategies. Agents that target various aspects of CSCs, namely specific markers, signaling, dormancy, proliferation, metabolism, autophagy, drug resistance, and niches, which have generated promising preclinical results and are now entering clinical trial, were reviewed. We hope our work provides a better understanding of CSC pathology and encourages scientists to engage in more creative attempts to develop more effective strategies to achieve better treatment outcomes in the future.

The considerable disease heterogeneity, both intertumor and intratumor, remains the major obstacle to identifying actionable targets in TNBC. Due to the lack of well-defined molecular targets, current treatment options for TNBC commonly focus on cytotoxic chemotherapy. Despite different TNBC subtypes presenting distinct treatment responses, subtype-based chemo regimen selection 
remains debatable. In addition, cytotoxic chemotherapy against actively dividing cells within a tumor is not capable of eliminating dormant CSCs, which results in low pCR and short DFS in patients with TNBC. Although more aggressive chemotherapy has resulted in improved prognosis, it usually leads to serious deterioration in quality of life. This has prompted endeavors to develop novel drugs and identify effective subtype-specific therapeutic strategies, such as anti-IGF-1R and anti- $\alpha 9-\mathrm{nAChR}$ in TNBCs (Figure 2).

Several studies over a number of years have examined target therapies against CSCs in hopes of eradicating MDR. However, only targeting these CSCs does not succeed in tumor eradication either. While "one size does not fit all TNBCs" is the lesson learned from the past, the same rule applies in so far as the previous failure in CSC-targeted therapy does not determine all cases. Recent studies have demonstrated satisfying results when they have repositioned a CSC-targeted regimen in other breast cancer prescriptions, such as in combination with chemotherapy or time-sequential treatment rather than co-treatment. Moreover, anti-IGF-1R or anti- $\alpha 9-\mathrm{nAChR}$ are reasonable strategies to combine with chemotherapies to attack the CSCs of TNBCs (Figure 2). Given the increasing knowledge of the relevance of the dynamic and changing nature of cancer and CSC populations, we predict that tailored therapeutic strategies alongside TNBC treatment will be the future gold standard.

Author Contributions: Formulated the theme and outline of the review, K.-L.L. and Y.-C.K.; reviewed the literature and drafted and revised the manuscript, K.-L.L. and Y.-C.K.; reviewed, revised, and finalized the manuscript, Y.-S.H. and Y.-H.H.

Funding: This work was financially supported by research grants from the Ministry of Science and Technology, Taiwan (Grant numbers: MOST 105-2628-B-038-008-MY3, MOST 106-3114-B-038-001, MOST 107-2321-B-038-002, MOST 107-2314-B-038-057, MOST 107-2314-B-038-061, MOST 108-2320-B-038-033-MY3, MOST 108-2314-B-038-006, and MOST 108-2321-B-038-003); Health and Welfare Surcharge of Tobacco Products (Grant numbers: MOHW103-TD-B-111-01, MOHW104-TDU-B-212-124-001, MOHW105-TDU-B-212-134001, MOHW106-TDU-B-212-144001, MOHW107-TDU-B-212-114014, and MOHW108-TDU-B-212-124014); Ministry of Education, Taiwan (Grant numbers: DP2-107-21121-01-T-02 and DP2-108-21121-01-T-02-02); Taipei Medical University (Grant numbers: TMU-T104-06, TMU-T105-06, TMU-T106-03, and 105TMU-CIT-01-3); Taipei Medical University Hospital (Grant numbers: 104TMU-TMUH-04 and 105TMU-TMUH-10); and "TMU Research Center of Cancer Translational Medicine" from The Featured Areas Research Center Program within the framework of the Higher Education Sprout Project by the Ministry of Education (MOE) in Taiwan. This manuscript was edited by Wallace Academic Editing.

Conflicts of Interest: None of the authors have any real or potential conflicts of interest.

\section{References}

1. Bray, F.; Ferlay, J.; Soerjomataram, I.; Siegel, R.L.; Torre, L.A.; Jemal, A. Global cancer statistics 2018: GLOBOCAN estimates of incidence and mortality worldwide for 36 cancers in 185 countries. CA Cancer J. Clin. 2018, 68, 394-424. [CrossRef] [PubMed]

2. Garrido-Castro, A.C.; Lin, N.U.; Polyak, K. Insights into Molecular Classifications of Triple-Negative Breast Cancer: Improving Patient Selection for Treatment. Cancer Discov. 2019, 9, 176-198. [CrossRef] [PubMed]

3. Trivers, K.F.; Lund, M.J.; Porter, P.L.; Liff, J.M.; Flagg, E.W.; Coates, R.J.; Eley, J.W. The epidemiology of triple-negative breast cancer, including race. Cancer Causes Control 2009, 20, 1071-1082. [CrossRef] [PubMed]

4. Mustacchi, G.; De Laurentiis, M. The role of taxanes in triple-negative breast cancer: literature review. Drug Des. Devel. Ther. 2015, 9, 4303-4318. [CrossRef] [PubMed]

5. Liedtke, C.; Mazouni, C.; Hess, K.R.; Andre, F.; Tordai, A.; Mejia, J.A.; Symmans, W.F.; Gonzalez-Angulo, A.M.; Hennessy, B.; Green, M.; et al. Response to neoadjuvant therapy and long-term survival in patients with triple-negative breast cancer. J. Clin. Oncol. 2008, 26, 1275-1281. [CrossRef] [PubMed]

6. Thomas, E.S. Ixabepilone plus capecitabine for metastatic breast cancer progressing after anthracycline and taxane treatment. J. Clin. Oncol. 2008, 26, 2223. [CrossRef] [PubMed]

7. Livasy, C.A.; Karaca, G.; Nanda, R.; Tretiakova, M.S.; Olopade, O.I.; Moore, D.T.; Perou, C.M. Phenotypic evaluation of the basal-like subtype of invasive breast carcinoma. Mod. Pathol. 2006, 19, 264-271. [CrossRef]

8. Lehmann, B.D.; Bauer, J.A.; Chen, X.; Sanders, M.E.; Chakravarthy, A.B.; Shyr, Y.; Pietenpol, J.A. Identification of human triple-negative breast cancer subtypes and preclinical models for selection of targeted therapies. J. Clin. Investig. 2011, 121, 2750-2767. [CrossRef] 
9. Teschendorff, A.E.; Miremadi, A.; Pinder, S.E.; Ellis, I.O.; Caldas, C. An immune response gene expression module identifies a good prognosis subtype in estrogen receptor negative breast cancer. Genome. Biol. 2007, 8, R157. [CrossRef]

10. Prat, A.; Parker, J.S.; Karginova, O.; Fan, C.; Livasy, C.; Herschkowitz, J.I.; He, X.; Perou, C.M. Phenotypic and molecular characterization of the claudin-low intrinsic subtype of breast cancer. Breast Cancer Res. 2010, 12, R68. [CrossRef]

11. Sorlie, T.; Perou, C.M.; Tibshirani, R.; Aas, T.; Geisler, S.; Johnsen, H.; Hastie, T.; Eisen, M.B.; van de Rijn, M.; Jeffrey, S.S.; et al. Gene expression patterns of breast carcinomas distinguish tumor subclasses with clinical implications. Proc. Natl. Acad. Sci. USA 2001, 98, 10869-10874. [CrossRef] [PubMed]

12. Perou, C.M.; Sorlie, T.; Eisen, M.B.; van de Rijn, M.; Jeffrey, S.S.; Rees, C.A.; Pollack, J.R.; Ross, D.T.; Johnsen, H.; Akslen, L.A.; et al. Molecular portraits of human breast tumours. Nature 2000, 406, 747-752. [CrossRef] [PubMed]

13. Rakha, E.A.; Reis-Filho, J.S.; Ellis, I.O. Basal-like breast cancer: a critical review. J. Clin. Oncol. 2008, 26, 2568-2581. [CrossRef] [PubMed]

14. Yersal, O.; Barutca, S. Biological subtypes of breast cancer: Prognostic and therapeutic implications. World J. Clin. Oncol. 2014, 5, 412-424. [CrossRef] [PubMed]

15. Kreike, B.; van Kouwenhove, M.; Horlings, H.; Weigelt, B.; Peterse, H.; Bartelink, H.; van de Vijver, M.J. Gene expression profiling and histopathological characterization of triple-negative/basal-like breast carcinomas. Breast Cancer Res. 2007, 9, R65. [CrossRef] [PubMed]

16. Rody, A.; Karn, T.; Liedtke, C.; Pusztai, L.; Ruckhaeberle, E.; Hanker, L.; Gaetje, R.; Solbach, C.; Ahr, A.; Metzler, D.; et al. A clinically relevant gene signature in triple negative and basal-like breast cancer. Breast Cancer Res. 2011, 13, R97. [CrossRef] [PubMed]

17. Lehmann, B.D.; Jovanović, B.; Chen, X.; Estrada, M.V.; Johnson, K.N.; Shyr, Y.; Moses, H.L.; Sanders, M.E.; Pietenpol, J.A. Refinement of Triple-Negative Breast Cancer Molecular Subtypes: Implications for Neoadjuvant Chemotherapy Selection. PLoS ONE 2016, 11, e0157368. [CrossRef] [PubMed]

18. Burstein, M.D.; Tsimelzon, A.; Poage, G.M.; Covington, K.R.; Contreras, A.; Fuqua, S.A.; Savage, M.I.; Osborne, C.K.; Hilsenbeck, S.G.; Chang, J.C.; et al. Comprehensive genomic analysis identifies novel subtypes and targets of triple-negative breast cancer. Clin. Cancer Res. 2015, 21, 1688-1698. [CrossRef] [PubMed]

19. Elsawaf, Z.; Sinn, H.P.; Rom, J.; Bermejo, J.L.; Schneeweiss, A.; Aulmann, S. Biological subtypes of triple-negative breast cancer are associated with distinct morphological changes and clinical behaviour. Breast 2013, 22, 986-992. [CrossRef]

20. Prado-Vazquez, G.; Gamez-Pozo, A.; Trilla-Fuertes, L.; Arevalillo, J.M.; Zapater-Moros, A.; Ferrer-Gomez, M.; Diaz-Almiron, M.; Lopez-Vacas, R.; Navarro, H.; Main, P.; et al. A novel approach to triple-negative breast cancer molecular classification reveals a luminal immune-positive subgroup with good prognoses. Sci. Rep. 2019, 9, 1538. [CrossRef]

21. Masuda, H.; Baggerly, K.A.; Wang, Y.; Zhang, Y.; Gonzalez-Angulo, A.M.; Meric-Bernstam, F.; Valero, V.; Lehmann, B.D.; Pietenpol, J.A.; Hortobagyi, G.N.; et al. Differential response to neoadjuvant chemotherapy among 7 triple-negative breast cancer molecular subtypes. Clin. Cancer Res. 2013, 19, 5533-5540. [CrossRef] [PubMed]

22. Jovanovic, B.; Beeler, J.S.; Pickup, M.W.; Chytil, A.; Gorska, A.E.; Ashby, W.J.; Lehmann, B.D.; Zijlstra, A.; Pietenpol, J.A.; Moses, H.L. Transforming growth factor beta receptor type III is a tumor promoter in mesenchymal-stem like triple negative breast cancer. Breast Cancer Res. 2014, 16, R69. [CrossRef] [PubMed]

23. Shah, S.P.; Roth, A.; Goya, R.; Oloumi, A.; Ha, G.; Zhao, Y.; Turashvili, G.; Ding, J.; Tse, K.; Haffari, G.; et al. The clonal and mutational evolution spectrum of primary triple-negative breast cancers. Nature 2012, 486, 395-399. [CrossRef] [PubMed]

24. von Minckwitz, G.; Untch, M.; Blohmer, J.U.; Costa, S.D.; Eidtmann, H.; Fasching, P.A.; Gerber, B.; Eiermann, W.; Hilfrich, J.; Huober, J.; et al. Definition and impact of pathologic complete response on prognosis after neoadjuvant chemotherapy in various intrinsic breast cancer subtypes. J. Clin. Oncol. 2012, 30, 1796-1804. [CrossRef] [PubMed]

25. Amir, E.; Clemons, M.; Purdie, C.A.; Miller, N.; Quinlan, P.; Geddie, W.; Coleman, R.E.; Freedman, O.C.; Jordan, L.B.; Thompson, A.M. Tissue confirmation of disease recurrence in breast cancer patients: pooled analysis of multi-centre, multi-disciplinary prospective studies. Cancer Treat. Rev. 2012, 38, 708-714. [CrossRef] [PubMed] 
26. Petrelli, F.; Coinu, A.; Borgonovo, K.; Cabiddu, M.; Ghilardi, M.; Lonati, V.; Barni, S. The value of platinum agents as neoadjuvant chemotherapy in triple-negative breast cancers: a systematic review and meta-analysis. Breast Cancer Res. Treat. 2014, 144, 223-232. [CrossRef] [PubMed]

27. Silver, D.P.; Richardson, A.L.; Eklund, A.C.; Wang, Z.C.; Szallasi, Z.; Li, Q.; Juul, N.; Leong, C.O.; Calogrias, D.; Buraimoh, A.; et al. Efficacy of neoadjuvant Cisplatin in triple-negative breast cancer. J. Clin. Oncol. 2010, 28, 1145-1153. [CrossRef]

28. Loi, S.; Pommey, S.; Haibe-Kains, B.; Beavis, P.A.; Darcy, P.K.; Smyth, M.J.; Stagg, J. CD73 promotes anthracycline resistance and poor prognosis in triple negative breast cancer. Proc. Natl. Acad. Sci. USA 2013, 110, 11091-11096. [CrossRef]

29. Cancer Genome Atlas, N. Comprehensive molecular portraits of human breast tumours. Nature 2012, 490, 61-70. [CrossRef]

30. Farmer, H.; McCabe, N.; Lord, C.J.; Tutt, A.N.; Johnson, D.A.; Richardson, T.B.; Santarosa, M.; Dillon, K.J.; Hickson, I.; Knights, C.; et al. Targeting the DNA repair defect in BRCA mutant cells as a therapeutic strategy. Nature 2005, 434, 917-921. [CrossRef]

31. Carey, L.; Winer, E.; Viale, G.; Cameron, D.; Gianni, L. Triple-negative breast cancer: disease entity or title of convenience? Nat. Rev. Clin. Oncol. 2010, 7, 683-692. [CrossRef] [PubMed]

32. McCabe, N.; Turner, N.C.; Lord, C.J.; Kluzek, K.; Bialkowska, A.; Swift, S.; Giavara, S.; O'Connor, M.J.; Tutt, A.N.; Zdzienicka, M.Z.; et al. Deficiency in the repair of DNA damage by homologous recombination and sensitivity to poly(ADP-ribose) polymerase inhibition. Cancer Res. 2006, 66, 8109-8115. [CrossRef] [PubMed]

33. Tentori, L.; Graziani, G. Chemopotentiation by PARP inhibitors in cancer therapy. Pharmacol. Res. 2005, 52, 25-33. [CrossRef] [PubMed]

34. Robson, M.E.; Tung, N.; Conte, P.; Im, S.A.; Senkus, E.; Xu, B.; Masuda, N.; Delaloge, S.; Li, W.; Armstrong, A.; et al. OlympiAD final overall survival and tolerability results: Olaparib versus chemotherapy treatment of physician's choice in patients with a germline BRCA mutation and HER2-negative metastatic breast cancer. Ann. Oncol. 2019, 30, 558-566. [CrossRef] [PubMed]

35. Robson, M.; Im, S.A.; Senkus, E.; Xu, B.; Domchek, S.M.; Masuda, N.; Delaloge, S.; Li, W.; Tung, N.; Armstrong, A.; et al. Olaparib for Metastatic Breast Cancer in Patients with a Germline BRCA Mutation. N. Engl. J. Med. 2017, 377, 523-533. [CrossRef] [PubMed]

36. Dent, R.A.; Lindeman, G.J.; Clemons, M.; Wildiers, H.; Chan, A.; McCarthy, N.J.; Singer, C.F.; Lowe, E.S.; Watkins, C.L.; Carmichael, J. Phase I trial of the oral PARP inhibitor olaparib in combination with paclitaxel for first- or second-line treatment of patients with metastatic triple-negative breast cancer. Breast Cancer Res. 2013, 15, R88. [CrossRef]

37. Fong, P.C.; Boss, D.S.; Yap, T.A.; Tutt, A.; Wu, P.; Mergui-Roelvink, M.; Mortimer, P.; Swaisland, H.; Lau, A.; O'Connor, M.J.; et al. Inhibition of poly(ADP-ribose) polymerase in tumors from BRCA mutation carriers. N. Engl. J. Med. 2009, 361, 123-134. [CrossRef]

38. Matulonis, U.A.; Wulf, G.M.; Barry, W.T.; Birrer, M.; Westin, S.N.; Farooq, S.; Bell-McGuinn, K.M.; Obermayer, E.; Whalen, C.; Spagnoletti, T.; et al. Phase I dose escalation study of the PI3kinase pathway inhibitor BKM120 and the oral poly (ADP ribose) polymerase (PARP) inhibitor olaparib for the treatment of high-grade serous ovarian and breast cancer. Ann. Oncol. 2017, 28, 512-518. [CrossRef]

39. O'Shaughnessy, J.; Osborne, C.; Pippen, J.E.; Yoffe, M.; Patt, D.; Rocha, C.; Koo, I.C.; Sherman, B.M.; Bradley, C. Iniparib plus chemotherapy in metastatic triple-negative breast cancer. N. Engl. J. Med. 2011, 364, $205-214$. [CrossRef]

40. Palma, J.P.; Rodriguez, L.E.; Bontcheva-Diaz, V.D.; Bouska, J.J.; Bukofzer, G.; Colon-Lopez, M.; Guan, R.; Jarvis, K.; Johnson, E.F.; Klinghofer, V.; et al. The PARP inhibitor, ABT-888 potentiates temozolomide: correlation with drug levels and reduction in PARP activity in vivo. Anticancer Res. 2008, 28, 2625-2635.

41. Tentori, L.; Muzi, A.; Dorio, A.S.; Scarsella, M.; Leonetti, C.; Shah, G.M.; Xu, W.; Camaioni, E.; Gold, B.; Pellicciari, R.; et al. Pharmacological inhibition of poly(ADP-ribose) polymerase (PARP) activity in PARP-1 silenced tumour cells increases chemosensitivity to temozolomide and to a N3-adenine selective methylating agent. Curr. Cancer Drug Targets 2010, 10, 368-383. [CrossRef] [PubMed] 
42. Tutt, A.; Robson, M.; Garber, J.E.; Domchek, S.M.; Audeh, M.W.; Weitzel, J.N.; Friedlander, M.; Arun, B.; Loman, N.; Schmutzler, R.K.; et al. Oral poly(ADP-ribose) polymerase inhibitor olaparib in patients with BRCA1 or BRCA2 mutations and advanced breast cancer: a proof-of-concept trial. Lancet 2010, 376, 235-244. [CrossRef]

43. Carey, L.A.; Rugo, H.S.; Marcom, P.K.; Mayer, E.L.; Esteva, F.J.; Ma, C.X.; Liu, M.C.; Storniolo, A.M.; Rimawi, M.F.; Forero-Torres, A.; et al. TBCRC 001: randomized phase II study of cetuximab in combination with carboplatin in stage IV triple-negative breast cancer. J. Clin. Oncol. 2012, 30, 2615-2623. [CrossRef] [PubMed]

44. Baselga, J.; Gomez, P.; Greil, R.; Braga, S.; Climent, M.A.; Wardley, A.M.; Kaufman, B.; Stemmer, S.M.; Pego, A.; Chan, A.; et al. Randomized phase II study of the anti-epidermal growth factor receptor monoclonal antibody cetuximab with cisplatin versus cisplatin alone in patients with metastatic triple-negative breast cancer. J. Clin. Oncol. 2013, 31, 2586-2592. [CrossRef] [PubMed]

45. Miller, K.; Wang, M.; Gralow, J.; Dickler, M.; Cobleigh, M.; Perez, E.A.; Shenkier, T.; Cella, D.; Davidson, N.E. Paclitaxel plus bevacizumab versus paclitaxel alone for metastatic breast cancer. N. Engl. J. Med. 2007, 357, 2666-2676. [CrossRef] [PubMed]

46. Miles, D.W.; Chan, A.; Dirix, L.Y.; Cortes, J.; Pivot, X.; Tomczak, P.; Delozier, T.; Sohn, J.H.; Provencher, L.; Puglisi, F.; et al. Phase III study of bevacizumab plus docetaxel compared with placebo plus docetaxel for the first-line treatment of human epidermal growth factor receptor 2-negative metastatic breast cancer. J. Clin. Oncol. 2010, 28, 3239-3247. [CrossRef] [PubMed]

47. Miles, D.W.; Dieras, V.; Cortes, J.; Duenne, A.A.; Yi, J.; O'Shaughnessy, J. First-line bevacizumab in combination with chemotherapy for HER2-negative metastatic breast cancer: pooled and subgroup analyses of data from 2447 patients. Ann. Oncol. 2013, 24, 2773-2780. [CrossRef]

48. Bell, R.; Brown, J.; Parmar, M.; Toi, M.; Suter, T.; Steger, G.G.; Pivot, X.; Mackey, J.; Jackisch, C.; Dent, R.; et al. Final efficacy and updated safety results of the randomized phase III BEATRICE trial evaluating adjuvant bevacizumab-containing therapy in triple-negative early breast cancer. Ann. Oncol. 2017, 28, 754-760. [CrossRef]

49. Brufsky, A.M.; Hurvitz, S.; Perez, E.; Swamy, R.; Valero, V.; O’Neill, V.; Rugo, H.S. RIBBON-2: a randomized, double-blind, placebo-controlled, phase III trial evaluating the efficacy and safety of bevacizumab in combination with chemotherapy for second-line treatment of human epidermal growth factor receptor 2-negative metastatic breast cancer. J. Clin. Oncol. 2011, 29, 4286-4293.

50. Cochrane, D.R.; Bernales, S.; Jacobsen, B.M.; Cittelly, D.M.; Howe, E.N.; D'Amato, N.C.; Spoelstra, N.S.; Edgerton, S.M.; Jean, A.; Guerrero, J.; et al. Role of the androgen receptor in breast cancer and preclinical analysis of enzalutamide. Breast Cancer Res. 2014, 16, R7. [CrossRef]

51. Collins, L.C.; Cole, K.S.; Marotti, J.D.; Hu, R.; Schnitt, S.J.; Tamimi, R.M. Androgen receptor expression in breast cancer in relation to molecular phenotype: results from the Nurses' Health Study. Mod. Pathol. 2011, 24, 924-931. [CrossRef] [PubMed]

52. Gucalp, A.; Tolaney, S.; Isakoff, S.J.; Ingle, J.N.; Liu, M.C.; Carey, L.A.; Blackwell, K.; Rugo, H.; Nabell, L.; Forero, A.; et al. Phase II trial of bicalutamide in patients with androgen receptor-positive, estrogen receptor-negative metastatic Breast Cancer. Clin. Cancer Res. 2013, 19, 5505-5512. [CrossRef] [PubMed]

53. Traina, T.A.; Miller, K.; Yardley, D.A.; Eakle, J.; Schwartzberg, L.S.; O'Shaughnessy, J.; Gradishar, W.; Schmid, P.; Winer, E.; Kelly, C.; et al. Enzalutamide for the Treatment of Androgen Receptor-Expressing Triple-Negative Breast Cancer. J. Clin. Oncol. 2018, 36, 884-890. [CrossRef] [PubMed]

54. Francisco, L.M.; Salinas, V.H.; Brown, K.E.; Vanguri, V.K.; Freeman, G.J.; Kuchroo, V.K.; Sharpe, A.H. PD-L1 regulates the development, maintenance, and function of induced regulatory T cells. J. Exp. Med. 2009, 206, 3015-3029. [CrossRef] [PubMed]

55. Tumeh, P.C.; Harview, C.L.; Yearley, J.H.; Shintaku, I.P.; Taylor, E.J.; Robert, L.; Chmielowski, B.; Spasic, M.; Henry, G.; Ciobanu, V.; et al. PD-1 blockade induces responses by inhibiting adaptive immune resistance. Nature 2014, 515, 568-571. [CrossRef]

56. Nanda, R.; Chow, L.Q.; Dees, E.C.; Berger, R.; Gupta, S.; Geva, R.; Pusztai, L.; Pathiraja, K.; Aktan, G.; Cheng, J.D.; et al. Pembrolizumab in Patients With Advanced Triple-Negative Breast Cancer: Phase $\mathrm{Ib}$ KEYNOTE-012 Study. J. Clin. Oncol. 2016, 34, 2460-2467. [CrossRef] 
57. Adams, S.; Loi, S.; Toppmeyer, D.; Cescon, D.W.; De Laurentiis, M.; Nanda, R.; Winer, E.P.; Mukai, H.; Tamura, K.; Armstrong, A.; et al. Pembrolizumab monotherapy for previously untreated, PD-L1-positive, metastatic triple-negative breast cancer: cohort B of the phase II KEYNOTE-086 study. Ann. Oncol. 2019, 30, 405-411. [CrossRef]

58. Adams, S.; Schmid, P.; Rugo, H.S.; Winer, E.P.; Loirat, D.; Awada, A.; Cescon, D.W.; Iwata, H.; Campone, M.; Nanda, R.; et al. Pembrolizumab monotherapy for previously treated metastatic triple-negative breast cancer: cohort A of the phase II KEYNOTE-086 study. Ann. Oncol. 2019, 30, 397-404. [CrossRef]

59. Schmid, P.; Adams, S.; Rugo, H.S.; Schneeweiss, A.; Barrios, C.H.; Iwata, H.; Dieras, V.; Hegg, R.; Im, S.A.; Shaw Wright, G.; et al. Atezolizumab and Nab-Paclitaxel in Advanced Triple-Negative Breast Cancer. N. Engl. J. Med. 2018, 379, 2108-2121. [CrossRef]

60. Garcia-Mayea, Y.; Mir, C.; Masson, F.; Paciucci, R.; ME, L.L. Insights into new mechanisms and models of cancer stem cell multidrug resistance. Semin. Cancer Biol. 2019, (in press). [CrossRef]

61. Al-Hajj, M.; Wicha, M.S.; Benito-Hernandez, A.; Morrison, S.J.; Clarke, M.F. Prospective identification of tumorigenic breast cancer cells. Proc. Natl. Acad. Sci. USA 2003, 100, 3983-3988. [CrossRef] [PubMed]

62. Hatina, J. The dynamics of cancer stem cells. Neoplasma 2012, 59, 700-707. [CrossRef] [PubMed]

63. Talukdar, S.; Bhoopathi, P.; Emdad, L.; Das, S.; Sarkar, D.; Fisher, P.B. Dormancy and cancer stem cells: An enigma for cancer therapeutic targeting. Adv. Cancer Res. 2019, 141, 43-84. [PubMed]

64. Batlle, E.; Clevers, H. Cancer stem cells revisited. Nat. Med. 2017, 23, 1124-1134. [CrossRef] [PubMed]

65. Puig, I.; Tenbaum, S.P.; Chicote, I.; Arques, O.; Martinez-Quintanilla, J.; Cuesta-Borras, E.; Ramirez, L.; Gonzalo, P.; Soto, A.; Aguilar, S.; et al. TET2 controls chemoresistant slow-cycling cancer cell survival and tumor recurrence. J. Clin. Investig. 2018, 128, 3887-3905. [CrossRef]

66. Yamamoto, Y.; Yoshioka, Y.; Minoura, K.; Takahashi, R.U.; Takeshita, F.; Taya, T.; Horii, R.; Fukuoka, Y.; Kato, T.; Kosaka, N.; et al. An integrative genomic analysis revealed the relevance of microRNA and gene expression for drug-resistance in human breast cancer cells. Mol. Cancer 2011, 10, 135. [CrossRef] [PubMed]

67. Schmidt, F.; Efferth, T. Tumor Heterogeneity, Single-Cell Sequencing, and Drug Resistance. Pharmaceuticals 2016, 9, 33. [CrossRef]

68. Efferth, T.; Konkimalla, V.B.; Wang, Y.F.; Sauerbrey, A.; Meinhardt, S.; Zintl, F.; Mattern, J.; Volm, M. Prediction of broad spectrum resistance of tumors towards anticancer drugs. Clin. Cancer Res. 2008, 14, 2405-2412. [CrossRef]

69. Longley, D.B.; Johnston, P.G. Molecular mechanisms of drug resistance. J. Pathol. 2005, 205, $275-292$. [CrossRef]

70. Naik, P.P.; Das, D.N.; Panda, P.K.; Mukhopadhyay, S.; Sinha, N.; Praharaj, P.P.; Agarwal, R.; Bhutia, S.K. Implications of cancer stem cells in developing therapeutic resistance in oral cancer. Oral. Oncol. 2016, 62, 122-135. [CrossRef]

71. Bao, S.; Wu, Q.; McLendon, R.E.; Hao, Y.; Shi, Q.; Hjelmeland, A.B.; Dewhirst, M.W.; Bigner, D.D.; Rich, J.N. Glioma stem cells promote radioresistance by preferential activation of the DNA damage response. Nature 2006, 444, 756-760. [CrossRef] [PubMed]

72. Carnero, A.; Garcia-Mayea, Y.; Mir, C.; Lorente, J.; Rubio, I.T.; ME, L.L. The cancer stem-cell signaling network and resistance to therapy. Cancer Treat. Rev. 2016, 49, 25-36. [CrossRef] [PubMed]

73. Dallas, N.A.; Xia, L.; Fan, F.; Gray, M.J.; Gaur, P.; van Buren, G., 2nd; Samuel, S.; Kim, M.P.; Lim, S.J.; Ellis, L.M. Chemoresistant colorectal cancer cells, the cancer stem cell phenotype, and increased sensitivity to insulin-like growth factor-I receptor inhibition. Cancer Res. 2009, 69, 1951-1957. [CrossRef] [PubMed]

74. Ricardo, S.; Vieira, A.F.; Gerhard, R.; Leitao, D.; Pinto, R.; Cameselle-Teijeiro, J.F.; Milanezi, F.; Schmitt, F.; Paredes, J. Breast cancer stem cell markers CD44, CD24 and ALDH1: expression distribution within intrinsic molecular subtype. J. Clin. Pathol. 2011, 64, 937-946. [CrossRef] [PubMed]

75. Chen, Y.; Song, J.; Jiang, Y.; Yu, C.; Ma, Z. Predictive value of CD44 and CD24 for prognosis and chemotherapy response in invasive breast ductal carcinoma. Int. J. Clin. Exp. Pathol. 2015, 8, 11287-11295.

76. Lin, Y.; Zhong, Y.; Guan, H.; Zhang, X.; Sun, Q. CD44+/CD24- phenotype contributes to malignant relapse following surgical resection and chemotherapy in patients with invasive ductal carcinoma. J. Exp. Clin. Cancer Res. 2012, 31, 59. [CrossRef]

77. Li, H.; Ma, F.; Wang, H.; Lin, C.; Fan, Y.; Zhang, X.; Qian, H.; Xu, B. Stem cell marker aldehyde dehydrogenase 1 (ALDH1)-expressing cells are enriched in triple-negative breast cancer. Int. J. Biol. Markers 2013, 28, e357-364. [CrossRef] 
78. Ma, F.; Li, H.; Li, Y.; Ding, X.; Wang, H.; Fan, Y.; Lin, C.; Qian, H.; Xu, B. Aldehyde dehydrogenase 1 (ALDH1) expression is an independent prognostic factor in triple negative breast cancer (TNBC). Medicine 2017, 96, e6561. [CrossRef]

79. Ohi, Y.; Umekita, Y.; Yoshioka, T.; Souda, M.; Rai, Y.; Sagara, Y.; Sagara, Y.; Sagara, Y.; Tanimoto, A. Aldehyde dehydrogenase 1 expression predicts poor prognosis in triple-negative breast cancer. Histopathology 2011, 59, 776-780. [CrossRef]

80. Moreira, M.P.; da Conceicao Braga, L.; Cassali, G.D.; Silva, L.M. STAT3 as a promising chemoresistance biomarker associated with the CD44(+/high)/CD24(-/low)/ALDH(+) BCSCs-like subset of the triple-negative breast cancer (TNBC) cell line. Exp. Cell Res. 2018, 363, 283-290. [CrossRef]

81. Barker, N.; van Es, J.H.; Kuipers, J.; Kujala, P.; van den Born, M.; Cozijnsen, M.; Haegebarth, A.; Korving, J.; Begthel, H.; Peters, P.J.; et al. Identification of stem cells in small intestine and colon by marker gene Lgr5. Nature 2007, 449, 1003-1007. [CrossRef] [PubMed]

82. Prieto-Vila, M.; Takahashi, R.U.; Usuba, W.; Kohama, I.; Ochiya, T. Drug Resistance Driven by Cancer Stem Cells and Their Niche. Int. J. Mol. Sci. 2017, 18, 2574. [CrossRef]

83. Kalluri, R.; Zeisberg, M. Fibroblasts in cancer. Nat. Rev. Cancer 2006, 6, 392-401. [CrossRef] [PubMed]

84. Martinez-Outschoorn, U.E.; Goldberg, A.; Lin, Z.; Ko, Y.H.; Flomenberg, N.; Wang, C.; Pavlides, S.; Pestell, R.G.; Howell, A.; Sotgia, F.; et al. Anti-estrogen resistance in breast cancer is induced by the tumor microenvironment and can be overcome by inhibiting mitochondrial function in epithelial cancer cells. Cancer Biol. Ther. 2011, 12, 924-938. [CrossRef]

85. Loeffler, M.; Kruger, J.A.; Niethammer, A.G.; Reisfeld, R.A. Targeting tumor-associated fibroblasts improves cancer chemotherapy by increasing intratumoral drug uptake. J. Clin. Investig. 2006, 116, 1955-1962. [CrossRef] [PubMed]

86. Acharyya, S.; Oskarsson, T.; Vanharanta, S.; Malladi, S.; Kim, J.; Morris, P.G.; Manova-Todorova, K.; Leversha, M.; Hogg, N.; Seshan, V.E.; et al. A CXCL1 paracrine network links cancer chemoresistance and metastasis. Cell 2012, 150, 165-178. [CrossRef] [PubMed]

87. Boelens, M.C.; Wu, T.J.; Nabet, B.Y.; Xu, B.; Qiu, Y.; Yoon, T.; Azzam, D.J.; Twyman-Saint Victor, C.; Wiemann, B.Z.; Ishwaran, H.; et al. Exosome transfer from stromal to breast cancer cells regulates therapy resistance pathways. Cell 2014, 159, 499-513. [CrossRef]

88. Rafii, A.; Mirshahi, P.; Poupot, M.; Faussat, A.M.; Simon, A.; Ducros, E.; Mery, E.; Couderc, B.; Lis, R.; Capdet, J.; et al. Oncologic trogocytosis of an original stromal cells induces chemoresistance of ovarian tumours. PLOS ONE 2008, 3, e3894. [CrossRef]

89. Calabrese, C.; Poppleton, H.; Kocak, M.; Hogg, T.L.; Fuller, C.; Hamner, B.; Oh, E.Y.; Gaber, M.W.; Finklestein, D.; Allen, M.; et al. A perivascular niche for brain tumor stem cells. Cancer Cell 2007, 11, 69-82. [CrossRef]

90. Tang, D.G. Understanding cancer stem cell heterogeneity and plasticity. Cell Res. 2012, 22, 457-472. [CrossRef]

91. Condeelis, J.; Pollard, J.W. Macrophages: obligate partners for tumor cell migration, invasion, and metastasis. Cell 2006, 124, 263-266. [CrossRef] [PubMed]

92. Bonde, A.K.; Tischler, V.; Kumar, S.; Soltermann, A.; Schwendener, R.A. Intratumoral macrophages contribute to epithelial-mesenchymal transition in solid tumors. BMC Cancer 2012, 12, 35. [CrossRef] [PubMed]

93. Korkaya, H.; Kim, G.I.; Davis, A.; Malik, F.; Henry, N.L.; Ithimakin, S.; Quraishi, A.A.; Tawakkol, N.; D'Angelo, R.; Paulson, A.K.; et al. Activation of an IL6 inflammatory loop mediates trastuzumab resistance in HER2+ breast cancer by expanding the cancer stem cell population. Mol. Cell 2012, 47, 570-584. [CrossRef] [PubMed]

94. Wong, G.S.; Rustgi, A.K. Matricellular proteins: priming the tumour microenvironment for cancer development and metastasis. Br. J. Cancer 2013, 108, 755-761. [CrossRef] [PubMed]

95. Murai, T. Lipid Raft-Mediated Regulation of Hyaluronan-CD44 Interactions in Inflammation and Cancer. Front. Immunol. 2015, 6, 420. [CrossRef] [PubMed]

96. Oskarsson, T.; Acharyya, S.; Zhang, X.H.; Vanharanta, S.; Tavazoie, S.F.; Morris, P.G.; Downey, R.J.; Manova-Todorova, K.; Brogi, E.; Massague, J. Breast cancer cells produce tenascin C as a metastatic niche component to colonize the lungs. Nat. Med. 2011, 17, 867-874. [CrossRef] [PubMed]

97. Gottesman, M.M.; Pastan, I. Biochemistry of multidrug resistance mediated by the multidrug transporter. Annu. Rev. Biochem. 1993, 62, 385-427. [CrossRef] [PubMed] 
98. Lobo, N.A.; Shimono, Y.; Qian, D.; Clarke, M.F. The biology of cancer stem cells. Annu. Rev. Cell Dev. Biol. 2007, 23, 675-699. [CrossRef] [PubMed]

99. Mao, Q.; Unadkat, J.D. Role of the breast cancer resistance protein (BCRP/ABCG2) in drug transport-an update. AAPS J. 2015, 17, 65-82. [CrossRef] [PubMed]

100. DeGorter, M.K.; Xia, C.Q.; Yang, J.J.; Kim, R.B. Drug transporters in drug efficacy and toxicity. Annu. Rev. Pharmacol. Toxicol. 2012, 52, 249-273. [CrossRef] [PubMed]

101. Goodell, M.A.; Brose, K.; Paradis, G.; Conner, A.S.; Mulligan, R.C. Isolation and functional properties of murine hematopoietic stem cells that are replicating in vivo. J. Exp. Med. 1996, 183, 1797-1806. [CrossRef] [PubMed]

102. Chuthapisith, S.; Eremin, J.; El-Sheemey, M.; Eremin, O. Breast cancer chemoresistance: emerging importance of cancer stem cells. Surg. Oncol. 2010, 19, 27-32. [CrossRef] [PubMed]

103. Scharenberg, C.W.; Harkey, M.A.; Torok-Storb, B. The ABCG2 transporter is an efficient Hoechst 33342 efflux pump and is preferentially expressed by immature human hematopoietic progenitors. Blood 2002, 99, 507-512. [CrossRef] [PubMed]

104. Saxena, M.; Stephens, M.A.; Pathak, H.; Rangarajan, A. Transcription factors that mediate epithelial-mesenchymal transition lead to multidrug resistance by upregulating ABC transporters. Cell Death Dis. 2011, 2, e179. [CrossRef] [PubMed]

105. Burger, H.; Foekens, J.A.; Look, M.P.; Meijer-van Gelder, M.E.; Klijn, J.G.; Wiemer, E.A.; Stoter, G.; Nooter, K. RNA expression of breast cancer resistance protein, lung resistance-related protein, multidrug resistance-associated proteins 1 and 2, and multidrug resistance gene 1 in breast cancer: correlation with chemotherapeutic response. Clin. Cancer Res. 2003, 9, 827-836. [PubMed]

106. Hawley, T.S.; Riz, I.; Yang, W.; Wakabayashi, Y.; Depalma, L.; Chang, Y.T.; Peng, W.; Zhu, J.; Hawley, R.G. Identification of an ABCB1 (P-glycoprotein)-positive carfilzomib-resistant myeloma subpopulation by the pluripotent stem cell fluorescent dye CDy1. Am. J. Hematol. 2013, 88, 265-272. [CrossRef]

107. Bradford, G.B.; Williams, B.; Rossi, R.; Bertoncello, I. Quiescence, cycling, and turnover in the primitive hematopoietic stem cell compartment. Exp. Hematol. 1997, 25, 445-453.

108. Zhu, L.F.; Hu, Y.; Yang, C.C.; Xu, X.H.; Ning, T.Y.; Wang, Z.L.; Ye, J.H.; Liu, L.K. Snail overexpression induces an epithelial to mesenchymal transition and cancer stem cell-like properties in SCC9 cells. Lab. Invest. 2012, 92, 744-752. [CrossRef]

109. Simon, M.C.; Keith, B. The role of oxygen availability in embryonic development and stem cell function. Nat. Rev. Mol. Cell Biol. 2008, 9, 285-296. [CrossRef]

110. Kuo, Y.C.; Au, H.K.; Hsu, J.L.; Wang, H.F.; Lee, C.J.; Peng, S.W.; Lai, S.C.; Wu, Y.C.; Ho, H.N.; Huang, Y.H. IGF-1R Promotes Symmetric Self-Renewal and Migration of Alkaline Phosphatase(+) Germ Stem Cells through HIF-2alpha-OCT4/CXCR4 Loop under Hypoxia. Stem Cell Reports 2018, 10, 524-537. [CrossRef]

111. Das, B.; Tsuchida, R.; Malkin, D.; Koren, G.; Baruchel, S.; Yeger, H. Hypoxia enhances tumor stemness by increasing the invasive and tumorigenic side population fraction. Stem Cells 2008, 26, 1818-1830. [CrossRef] [PubMed]

112. Semenza, G.L. Hydroxylation of HIF-1: oxygen sensing at the molecular level. Physiology (Bethesda) 2004, 19, 176-182. [CrossRef] [PubMed]

113. Schito, L.; Semenza, G.L. Hypoxia-Inducible Factors: Master Regulators of Cancer Progression. Trends Cancer 2016, 2, 758-770. [CrossRef] [PubMed]

114. Michiels, C. Physiological and pathological responses to hypoxia. Am. J. Pathol. 2004, 164, 1875-1882. [CrossRef]

115. Conley, S.J.; Gheordunescu, E.; Kakarala, P.; Newman, B.; Korkaya, H.; Heath, A.N.; Clouthier, S.G.; Wicha, M.S. Antiangiogenic agents increase breast cancer stem cells via the generation of tumor hypoxia. Proc. Natl. Acad. Sci. USA 2012, 109, 2784-2789. [CrossRef]

116. Schwab, L.P.; Peacock, D.L.; Majumdar, D.; Ingels, J.F.; Jensen, L.C.; Smith, K.D.; Cushing, R.C.; Seagroves, T.N. Hypoxia-inducible factor 1alpha promotes primary tumor growth and tumor-initiating cell activity in breast cancer. Breast Cancer Res. 2012, 14, R6. [CrossRef] [PubMed]

117. Gilkes, D.M.; Semenza, G.L. Role of hypoxia-inducible factors in breast cancer metastasis. Future Oncol. 2013, 9, 1623-1636. [CrossRef]

118. Semenza, G.L. Oxygen sensing, hypoxia-inducible factors, and disease pathophysiology. Annu. Rev. Pathol. 2014, 9, 47-71. [CrossRef] 
119. Buffa, F.M.; Harris, A.L.; West, C.M.; Miller, C.J. Large meta-analysis of multiple cancers reveals a common, compact and highly prognostic hypoxia metagene. Br. J. Cancer 2010, 102, 428-435. [CrossRef]

120. Cao, Y.; Eble, J.M.; Moon, E.; Yuan, H.; Weitzel, D.H.; Landon, C.D.; Nien, C.Y.; Hanna, G.; Rich, J.N.; Provenzale, J.M.; et al. Tumor cells upregulate normoxic HIF-1alpha in response to doxorubicin. Cancer Res. 2013, 73, 6230-6242. [CrossRef]

121. Samanta, D.; Gilkes, D.M.; Chaturvedi, P.; Xiang, L.; Semenza, G.L. Hypoxia-inducible factors are required for chemotherapy resistance of breast cancer stem cells. Proc. Natl. Acad. Sci. USA 2014, 111, E5429-E5438. [CrossRef] [PubMed]

122. Liu, L.; Salnikov, A.V.; Bauer, N.; Aleksandrowicz, E.; Labsch, S.; Nwaeburu, C.; Mattern, J.; Gladkich, J.; Schemmer, P.; Werner, J.; et al. Triptolide reverses hypoxia-induced epithelial-mesenchymal transition and stem-like features in pancreatic cancer by NF-kappaB downregulation. Int. J. Cancer 2014, 134, 2489-2503. [CrossRef] [PubMed]

123. Majmundar, A.J.; Wong, W.J.; Simon, M.C. Hypoxia-inducible factors and the response to hypoxic stress. Mol. Cell 2010, 40, 294-309. [CrossRef] [PubMed]

124. Almog, N. Molecular mechanisms underlying tumor dormancy. Cancer Lett 2010, 294, 139-146. [CrossRef] [PubMed]

125. Eun, K.; Ham, S.W.; Kim, H. Cancer stem cell heterogeneity: origin and new perspectives on CSC targeting. BMB Rep. 2017, 50, 117-125. [CrossRef] [PubMed]

126. Yamamori, T.; Yasui, H.; Yamazumi, M.; Wada, Y.; Nakamura, Y.; Nakamura, H.; Inanami, O. Ionizing radiation induces mitochondrial reactive oxygen species production accompanied by upregulation of mitochondrial electron transport chain function and mitochondrial content under control of the cell cycle checkpoint. Free Radic. Biol. Med. 2012, 53, 260-270. [CrossRef] [PubMed]

127. Wiseman, H.; Halliwell, B. Damage to DNA by reactive oxygen and nitrogen species: role in inflammatory disease and progression to cancer. Biochem. J. 1996, 313, 17-29. [CrossRef] [PubMed]

128. Clark, D.W.; Palle, K. Aldehyde dehydrogenases in cancer stem cells: potential as therapeutic targets. Ann. Transl. Med. 2016, 4, 518. [CrossRef] [PubMed]

129. Dontu, G.; Abdallah, W.M.; Foley, J.M.; Jackson, K.W.; Clarke, M.F.; Kawamura, M.J.; Wicha, M.S. In vitro propagation and transcriptional profiling of human mammary stem/progenitor cells. Genes Dev. 2003, 17, 1253-1270. [CrossRef]

130. Diehn, M.; Cho, R.W.; Lobo, N.A.; Kalisky, T.; Dorie, M.J.; Kulp, A.N.; Qian, D.; Lam, J.S.; Ailles, L.E.; Wong, M.; et al. Association of reactive oxygen species levels and radioresistance in cancer stem cells. Nature 2009, 458, 780-783. [CrossRef]

131. Li, X.S.; Xu, Q.; Fu, X.Y.; Luo, W.S. ALDH1A1 overexpression is associated with the progression and prognosis in gastric cancer. BMC Cancer 2014, 14, 705. [CrossRef] [PubMed]

132. Balicki, D. Moving forward in human mammary stem cell biology and breast cancer prognostication using ALDH1. Cell Stem Cell 2007, 1, 485-487. [CrossRef] [PubMed]

133. Huo, W.; Du, M.; Pan, X.; Zhu, X.; Li, Z. Prognostic value of ALDH1 expression in lung cancer: a meta-analysis. Int J. Clin. Exp. Med. 2015, 8, 2045-2051. [PubMed]

134. Ikeda, J.; Mamat, S.; Tian, T.; Wang, Y.; Luo, W.; Rahadiani, N.; Aozasa, K.; Morii, E. Reactive oxygen species and aldehyde dehydrogenase activity in Hodgkin lymphoma cells. Lab. Invest. 2012, 92, 606-614. [CrossRef] [PubMed]

135. Aponte, P.M.; Caicedo, A. Stemness in Cancer: Stem Cells, Cancer Stem Cells, and Their Microenvironment. Stem Cells Int. 2017, 2017, 5619472. [CrossRef] [PubMed]

136. Gasparetto, M.; Smith, C.A. ALDHs in normal and malignant hematopoietic cells: Potential new avenues for treatment of AML and other blood cancers. Chem. Biol. Interact. 2017, 276, 46-51. [CrossRef]

137. Takahashi, K.; Yamanaka, S. Induction of pluripotent stem cells from mouse embryonic and adult fibroblast cultures by defined factors. Cell 2006, 126, 663-676. [CrossRef]

138. Kida, K.; Ishikawa, T.; Yamada, A.; Shimada, K.; Narui, K.; Sugae, S.; Shimizu, D.; Tanabe, M.; Sasaki, T.; Ichikawa, Y.; et al. Effect of ALDH1 on prognosis and chemoresistance by breast cancer subtype. Breast Cancer Res. Treat. 2016, 156, 261-269. [CrossRef]

139. Kreso, A.; Dick, J.E. Evolution of the cancer stem cell model. Cell Stem Cell 2014, 14, 275-291. [CrossRef]

140. Karimi-Busheri, F.; Rasouli-Nia, A.; Mackey, J.R.; Weinfeld, M. Senescence evasion by MCF-7 human breast tumor-initiating cells. Breast Cancer Res. 2010, 12, R31. [CrossRef] 
141. Kim, N.H.; Kim, H.S.; Li, X.Y.; Lee, I.; Choi, H.S.; Kang, S.E.; Cha, S.Y.; Ryu, J.K.; Yoon, D.; Fearon, E.R.; et al. A p53/miRNA-34 axis regulates Snail1-dependent cancer cell epithelial-mesenchymal transition. J. Cell Biol. 2011, 195, 417-433. [CrossRef] [PubMed]

142. Chang, C.H.; Zhang, M.; Rajapakshe, K.; Coarfa, C.; Edwards, D.; Huang, S.; Rosen, J.M. Mammary Stem Cells and Tumor-Initiating Cells Are More Resistant to Apoptosis and Exhibit Increased DNA Repair Activity in Response to DNA Damage. Stem Cell Reports 2015, 5, 378-391. [CrossRef] [PubMed]

143. Zhang, P.; Wei, Y.; Wang, L.; Debeb, B.G.; Yuan, Y.; Zhang, J.; Yuan, J.; Wang, M.; Chen, D.; Sun, Y.; et al. ATM-mediated stabilization of ZEB1 promotes DNA damage response and radioresistance through CHK1. Nat. Cell Biol. 2014, 16, 864-875. [CrossRef] [PubMed]

144. Zhang, M.; Atkinson, R.L.; Rosen, J.M. Selective targeting of radiation-resistant tumor-initiating cells. Proc. Natl. Acad. Sci. USA 2010, 107, 3522-3527. [CrossRef] [PubMed]

145. Moreb, J.S.; Mohuczy, D.; Ostmark, B.; Zucali, J.R. RNAi-mediated knockdown of aldehyde dehydrogenase class-1A1 and class-3A1 is specific and reveals that each contributes equally to the resistance against 4-hydroperoxycyclophosphamide. Cancer Chemother. Pharmacol. 2007, 59, 127-136. [CrossRef] [PubMed]

146. Raha, D.; Wilson, T.R.; Peng, J.; Peterson, D.; Yue, P.; Evangelista, M.; Wilson, C.; Merchant, M.; Settleman, J. The cancer stem cell marker aldehyde dehydrogenase is required to maintain a drug-tolerant tumor cell subpopulation. Cancer Res. 2014, 74, 3579-3590. [CrossRef] [PubMed]

147. Aires, A.; Ocampo, S.M.; Simoes, B.M.; Josefa Rodriguez, M.; Cadenas, J.F.; Couleaud, P.; Spence, K.; Latorre, A.; Miranda, R.; Somoza, A.; et al. Multifunctionalized iron oxide nanoparticles for selective drug delivery to CD44-positive cancer cells. Nanotechnology 2016, 27, 065103. [CrossRef] [PubMed]

148. de Sousa, E.M.F.; Vermeulen, L. Wnt Signaling in Cancer Stem Cell Biology. Cancers 2016, 8, 60. [CrossRef] [PubMed]

149. Mamaeva, V.; Niemi, R.; Beck, M.; Ozliseli, E.; Desai, D.; Landor, S.; Gronroos, T.; Kronqvist, P.; Pettersen, I.K.; McCormack, E.; et al. Inhibiting Notch Activity in Breast Cancer Stem Cells by Glucose Functionalized Nanoparticles Carrying gamma-secretase Inhibitors. Mol. Ther. 2016, 24, 926-936. [CrossRef] [PubMed]

150. Cochrane, C.R.; Szczepny, A.; Watkins, D.N.; Cain, J.E. Hedgehog Signaling in the Maintenance of Cancer Stem Cells. Cancers 2015, 7, 1554-1585. [CrossRef]

151. Sekulic, A.; Migden, M.R.; Oro, A.E.; Dirix, L.; Lewis, K.D.; Hainsworth, J.D.; Solomon, J.A.; Yoo, S.; Arron, S.T.; Friedlander, P.A.; et al. Efficacy and safety of vismodegib in advanced basal-cell carcinoma. $N$. Engl. J. Med. 2012, 366, 2171-2179. [CrossRef] [PubMed]

152. Sekulic, A.; Migden, M.R.; Basset-Seguin, N.; Garbe, C.; Gesierich, A.; Lao, C.D.; Miller, C.; Mortier, L.; Murrell, D.F.; Hamid, O.; et al. Long-term safety and efficacy of vismodegib in patients with advanced basal cell carcinoma: final update of the pivotal ERIVANCE BCC study. BMC Cancer 2017, 17, 332. [CrossRef] [PubMed]

153. Finn, R.S.; Bengala, C.; Ibrahim, N.; Roche, H.; Sparano, J.; Strauss, L.C.; Fairchild, J.; Sy, O.; Goldstein, L.J. Dasatinib as a single agent in triple-negative breast cancer: results of an open-label phase 2 study. Clin. Cancer Res. 2011, 17, 6905-6913. [CrossRef] [PubMed]

154. Solzak, J.P.; Atale, R.V.; Hancock, B.A.; Sinn, A.L.; Pollok, K.E.; Jones, D.R.; Radovich, M. Dual PI3K and Wnt pathway inhibition is a synergistic combination against triple negative breast cancer. NPJ Breast Cancer 2017, 3, 17. [CrossRef] [PubMed]

155. Recasens, A.; Munoz, L. Targeting Cancer Cell Dormancy. Trends Pharmacol. Sci. 2019, 40, 128-141. [CrossRef] [PubMed]

156. Davies, C.; Pan, H.; Godwin, J.; Gray, R.; Arriagada, R.; Raina, V.; Abraham, M.; Medeiros Alencar, V.H.; Badran, A.; Bonfill, X.; et al. Long-term effects of continuing adjuvant tamoxifen to 10 years versus stopping at 5 years after diagnosis of oestrogen receptor-positive breast cancer: ATLAS, a randomised trial. Lancet 2013, 381, 805-816. [CrossRef]

157. Abderrahman, B.; Jordan, V.C. Rethinking Extended Adjuvant Antiestrogen Therapy to Increase Survivorship in Breast Cancer. JAMA Oncol. 2018, 4, 15-16. [CrossRef] [PubMed]

158. Barkan, D.; El Touny, L.H.; Michalowski, A.M.; Smith, J.A.; Chu, I.; Davis, A.S.; Webster, J.D.; Hoover, S.; Simpson, R.M.; Gauldie, J.; et al. Metastatic growth from dormant cells induced by a col-I-enriched fibrotic environment. Cancer Res. 2010, 70, 5706-5716. [CrossRef]

159. O'Leary, B.; Finn, R.S.; Turner, N.C. Treating cancer with selective CDK4/6 inhibitors. Nat. Rev. Clin. Oncol. 2016, 13, 417-430. [CrossRef] 
160. Bollard, J.; Miguela, V.; Ruiz de Galarreta, M.; Venkatesh, A.; Bian, C.B.; Roberto, M.P.; Tovar, V.; Sia, D.; Molina-Sanchez, P.; Nguyen, C.B.; et al. Palbociclib (PD-0332991), a selective CDK4/6 inhibitor, restricts tumour growth in preclinical models of hepatocellular carcinoma. Gut 2017, 66, 1286-1296. [CrossRef]

161. Shiozawa, Y.; Pedersen, E.A.; Patel, L.R.; Ziegler, A.M.; Havens, A.M.; Jung, Y.; Wang, J.; Zalucha, S.; Loberg, R.D.; Pienta, K.J.; et al. GAS6/AXL axis regulates prostate cancer invasion, proliferation, and survival in the bone marrow niche. Neoplasia 2010, 12, 116-127. [CrossRef] [PubMed]

162. Gao, H.; Chakraborty, G.; Lee-Lim, A.P.; Mo, Q.; Decker, M.; Vonica, A.; Shen, R.; Brogi, E.; Brivanlou, A.H.; Giancotti, F.G. The BMP inhibitor Coco reactivates breast cancer cells at lung metastatic sites. Cell 2012, 150, 764-779. [CrossRef] [PubMed]

163. Bragado, P.; Estrada, Y.; Parikh, F.; Krause, S.; Capobianco, C.; Farina, H.G.; Schewe, D.M.; Aguirre-Ghiso, J.A. TGF-beta2 dictates disseminated tumour cell fate in target organs through TGF-beta-RIII and p38alpha/beta signalling. Nat. Cell Biol. 2013, 15, 1351-1361. [CrossRef] [PubMed]

164. Tallman, M.S.; Altman, J.K. How I treat acute promyelocytic leukemia. Blood 2009, 114, 5126-5135. [CrossRef] [PubMed]

165. Yan, Y.; Li, Z.; Xu, X.; Chen, C.; Wei, W.; Fan, M.; Chen, X.; Li, J.J.; Wang, Y.; Huang, J. All-trans retinoic acids induce differentiation and sensitize a radioresistant breast cancer cells to chemotherapy. BMC Complement. Altern. Med. 2016, 16, 113. [CrossRef] [PubMed]

166. Boyerinas, B.; Zafrir, M.; Yesilkanal, A.E.; Price, T.T.; Hyjek, E.M.; Sipkins, D.A. Adhesion to osteopontin in the bone marrow niche regulates lymphoblastic leukemia cell dormancy. Blood 2013, 121, 4821-4831. [CrossRef] [PubMed]

167. Essers, M.A.; Offner, S.; Blanco-Bose, W.E.; Waibler, Z.; Kalinke, U.; Duchosal, M.A.; Trumpp, A. IFNalpha activates dormant haematopoietic stem cells in vivo. Nature 2009, 458, 904-908. [CrossRef] [PubMed]

168. Rajbhandari, N.; Lin, W.C.; Wehde, B.L.; Triplett, A.A.; Wagner, K.U. Autocrine IGF1 Signaling Mediates Pancreatic Tumor Cell Dormancy in the Absence of Oncogenic Drivers. Cell Rep. 2017, 18, 2243-2255. [CrossRef] [PubMed]

169. Vera-Ramirez, L.; Vodnala, S.K.; Nini, R.; Hunter, K.W.; Green, J.E. Autophagy promotes the survival of dormant breast cancer cells and metastatic tumour recurrence. Nat. Commun. 2018, 9, 1944. [CrossRef]

170. Goldman, A.; Majumder, B.; Dhawan, A.; Ravi, S.; Goldman, D.; Kohandel, M.; Majumder, P.K.; Sengupta, $\mathrm{S}$. Temporally sequenced anticancer drugs overcome adaptive resistance by targeting a vulnerable chemotherapy-induced phenotypic transition. Nat. Commun. 2015, 6, 6139. [CrossRef]

171. Wang, L.; Leite de Oliveira, R.; Huijberts, S.; Bosdriesz, E.; Pencheva, N.; Brunen, D.; Bosma, A.; Song, J.Y.; Zevenhoven, J.; Los-de Vries, G.T.; et al. An Acquired Vulnerability of Drug-Resistant Melanoma with Therapeutic Potential. Cell 2018, 173, 1413-1425. [CrossRef] [PubMed]

172. Lee, M.J.; Ye, A.S.; Gardino, A.K.; Heijink, A.M.; Sorger, P.K.; MacBeath, G.; Yaffe, M.B. Sequential application of anticancer drugs enhances cell death by rewiring apoptotic signaling networks. Cell 2012, 149, 780-794. [CrossRef] [PubMed]

173. Ranganathan, A.C.; Zhang, L.; Adam, A.P.; Aguirre-Ghiso, J.A. Functional coupling of p38-induced up-regulation of $\mathrm{BiP}$ and activation of RNA-dependent protein kinase-like endoplasmic reticulum kinase to drug resistance of dormant carcinoma cells. Cancer Res. 2006, 66, 1702-1711. [CrossRef] [PubMed]

174. Warburg, O. On the origin of cancer cells. Science 1956, 123, 309-314. [CrossRef] [PubMed]

175. Anderson, A.S.; Roberts, P.C.; Frisard, M.I.; Hulver, M.W.; Schmelz, E.M. Ovarian tumor-initiating cells display a flexible metabolism. Exp. Cell Res. 2014, 328, 44-57. [CrossRef] [PubMed]

176. Vander Heiden, M.G.; Cantley, L.C.; Thompson, C.B. Understanding the Warburg effect: the metabolic requirements of cell proliferation. Science 2009, 324, 1029-1033. [CrossRef] [PubMed]

177. Dong, C.; Yuan, T.; Wu, Y.; Wang, Y.; Fan, T.W.; Miriyala, S.; Lin, Y.; Yao, J.; Shi, J.; Kang, T.; et al. Loss of FBP1 by Snail-mediated repression provides metabolic advantages in basal-like breast cancer. Cancer Cell 2013, 23, 316-331. [CrossRef] [PubMed]

178. Ye, X.Q.; Li, Q.; Wang, G.H.; Sun, F.F.; Huang, G.J.; Bian, X.W.; Yu, S.C.; Qian, G.S. Mitochondrial and energy metabolism-related properties as novel indicators of lung cancer stem cells. Int. J. Cancer 2011, 129, 820-831. [CrossRef] [PubMed]

179. Janiszewska, M.; Suva, M.L.; Riggi, N.; Houtkooper, R.H.; Auwerx, J.; Clement-Schatlo, V.; Radovanovic, I.; Rheinbay, E.; Provero, P.; Stamenkovic, I. Imp2 controls oxidative phosphorylation and is crucial for preserving glioblastoma cancer stem cells. Genes Dev. 2012, 26, 1926-1944. [CrossRef] [PubMed] 
180. Pasto, A.; Bellio, C.; Pilotto, G.; Ciminale, V.; Silic-Benussi, M.; Guzzo, G.; Rasola, A.; Frasson, C.; Nardo, G.; Zulato, E.; et al. Cancer stem cells from epithelial ovarian cancer patients privilege oxidative phosphorylation, and resist glucose deprivation. Oncotarget 2014, 5, 4305-4319. [CrossRef] [PubMed]

181. Chen, E.I.; Hewel, J.; Krueger, J.S.; Tiraby, C.; Weber, M.R.; Kralli, A.; Becker, K.; Yates, J.R., 3rd; Felding-Habermann, B. Adaptation of energy metabolism in breast cancer brain metastases. Cancer Res. 2007, 67, 1472-1486. [CrossRef] [PubMed]

182. Vlashi, E.; Lagadec, C.; Vergnes, L.; Reue, K.; Frohnen, P.; Chan, M.; Alhiyari, Y.; Dratver, M.B.; Pajonk, F. Metabolic differences in breast cancer stem cells and differentiated progeny. Breast Cancer Res. Treat. 2014, 146, 525-534. [CrossRef] [PubMed]

183. Annibaldi, A.; Widmann, C. Glucose metabolism in cancer cells. Curr. Opin. Clin. Nutr. Metab. Care 2010, 13, 466-470. [CrossRef] [PubMed]

184. Krasnov, G.S.; Dmitriev, A.A.; Snezhkina, A.V.; Kudryavtseva, A.V. Deregulation of glycolysis in cancer: glyceraldehyde-3-phosphate dehydrogenase as a therapeutic target. Expert Opin. Ther. Targets 2013, 17, 681-693. [CrossRef] [PubMed]

185. Ceradini, D.J.; Kulkarni, A.R.; Callaghan, M.J.; Tepper, O.M.; Bastidas, N.; Kleinman, M.E.; Capla, J.M.; Galiano, R.D.; Levine, J.P.; Gurtner, G.C. Progenitor cell trafficking is regulated by hypoxic gradients through HIF-1 induction of SDF-1. Nat. Med. 2004, 10, 858-864. [CrossRef] [PubMed]

186. Feng, W.; Gentles, A.; Nair, R.V.; Huang, M.; Lin, Y.; Lee, C.Y.; Cai, S.; Scheeren, F.A.; Kuo, A.H.; Diehn, M. Targeting unique metabolic properties of breast tumor initiating cells. Stem Cells 2014, 32, 1734-1745. [CrossRef] [PubMed]

187. Ciavardelli, D.; Rossi, C.; Barcaroli, D.; Volpe, S.; Consalvo, A.; Zucchelli, M.; De Cola, A.; Scavo, E.; Carollo, R.; D'Agostino, D.; et al. Breast cancer stem cells rely on fermentative glycolysis and are sensitive to 2-deoxyglucose treatment. Cell Death Dis. 2014, 5, e1336. [CrossRef]

188. Chen, C.L.; Uthaya Kumar, D.B.; Punj, V.; Xu, J.; Sher, L.; Tahara, S.M.; Hess, S.; Machida, K. NANOG Metabolically Reprograms Tumor-Initiating Stem-like Cells through Tumorigenic Changes in Oxidative Phosphorylation and Fatty Acid Metabolism. Cell Metab. 2016, 23, 206-219. [CrossRef]

189. Serafino, A.; Zonfrillo, M.; Andreola, F.; Psaila, R.; Mercuri, L.; Moroni, N.; Renier, D.; Campisi, M.; Secchieri, C.; Pierimarchi, P. CD44-targeting for antitumor drug delivery: a new SN-38-hyaluronan bioconjugate for locoregional treatment of peritoneal carcinomatosis. Curr. Cancer Drug Targets 2011, 11, 572-585. [CrossRef]

190. Tamada, M.; Nagano, O.; Tateyama, S.; Ohmura, M.; Yae, T.; Ishimoto, T.; Sugihara, E.; Onishi, N.; Yamamoto, T.; Yanagawa, H.; et al. Modulation of glucose metabolism by CD44 contributes to antioxidant status and drug resistance in cancer cells. Cancer Res. 2012, 72, 1438-1448. [CrossRef]

191. Dupuy, F.; Tabaries, S.; Andrzejewski, S.; Dong, Z.; Blagih, J.; Annis, M.G.; Omeroglu, A.; Gao, D.; Leung, S.; Amir, E.; et al. PDK1-Dependent Metabolic Reprogramming Dictates Metastatic Potential in Breast Cancer. Cell Metab. 2015, 22, 577-589. [CrossRef] [PubMed]

192. Nazio, F.; Bordi, M.; Cianfanelli, V.; Locatelli, F.; Cecconi, F. Autophagy and cancer stem cells: molecular mechanisms and therapeutic applications. Cell Death Differ. 2019, 26, 690-702. [CrossRef] [PubMed]

193. Gong, C.; Bauvy, C.; Tonelli, G.; Yue, W.; Delomenie, C.; Nicolas, V.; Zhu, Y.; Domergue, V.; Marin-Esteban, V.; Tharinger, H.; et al. Beclin 1 and autophagy are required for the tumorigenicity of breast cancer stem-like/progenitor cells. Oncogene 2013, 32, 2261-2272. [CrossRef] [PubMed]

194. Chaterjee, M.; van Golen, K.L. Breast cancer stem cells survive periods of farnesyl-transferase inhibitor-induced dormancy by undergoing autophagy. Bone Marrow Res. 2011, 2011, 362938. [CrossRef] [PubMed]

195. Song, Y.J.; Zhang, S.S.; Guo, X.L.; Sun, K.; Han, Z.P.; Li, R.; Zhao, Q.D.; Deng, W.J.; Xie, X.Q.; Zhang, J.W.; et al. Autophagy contributes to the survival of CD133+ liver cancer stem cells in the hypoxic and nutrient-deprived tumor microenvironment. Cancer Lett. 2013, 339, 70-81. [CrossRef] [PubMed]

196. Zhang, D.; Zhao, Q.; Sun, H.; Yin, L.; Wu, J.; Xu, J.; He, T.; Yang, C.; Liang, C. Defective autophagy leads to the suppression of stem-like features of CD271(+) osteosarcoma cells. J. Biomed. Sci. 2016, 23, 82. [CrossRef] [PubMed]

197. Peng, Q.; Qin, J.; Zhang, Y.; Cheng, X.; Wang, X.; Lu, W.; Xie, X.; Zhang, S. Autophagy maintains the stemness of ovarian cancer stem cells by FOXA2. J. Exp. Clin. Cancer Res. 2017, 36, 171. [CrossRef] [PubMed] 
198. Buccarelli, M.; Marconi, M.; Pacioni, S.; De Pascalis, I.; D’Alessandris, Q.G.; Martini, M.; Ascione, B.; Malorni, W.; Larocca, L.M.; Pallini, R.; et al. Inhibition of autophagy increases susceptibility of glioblastoma stem cells to temozolomide by igniting ferroptosis. Cell Death Dis. 2018, 9, 841. [CrossRef]

199. Gong, C.; Song, E.; Codogno, P.; Mehrpour, M. The roles of BECN1 and autophagy in cancer are context dependent. Autophagy 2012, 8, 1853-1855. [CrossRef]

200. Wolf, J.; Dewi, D.L.; Fredebohm, J.; Muller-Decker, K.; Flechtenmacher, C.; Hoheisel, J.D.; Boettcher, M. A mammosphere formation RNAi screen reveals that ATG4A promotes a breast cancer stem-like phenotype. Breast Cancer Res. 2013, 15, R109. [CrossRef]

201. Yeo, S.K.; Wen, J.; Chen, S.; Guan, J.L. Autophagy Differentially Regulates Distinct Breast Cancer Stem-like Cells in Murine Models via EGFR/Stat3 and Tgfbeta/Smad Signaling. Cancer Res. 2016, 76, 3397-3410. [CrossRef] [PubMed]

202. Marcucci, F.; Ghezzi, P.; Rumio, C. The role of autophagy in the cross-talk between epithelial-mesenchymal transitioned tumor cells and cancer stem-like cells. Mol. Cancer 2017, 16, 3. [CrossRef] [PubMed]

203. Robert, T.; Vanoli, F.; Chiolo, I.; Shubassi, G.; Bernstein, K.A.; Rothstein, R.; Botrugno, O.A.; Parazzoli, D.; Oldani, A.; Minucci, S.; et al. HDACs link the DNA damage response, processing of double-strand breaks and autophagy. Nature 2011, 471, 74-79. [CrossRef] [PubMed]

204. Maycotte, P.; Jones, K.L.; Goodall, M.L.; Thorburn, J.; Thorburn, A. Autophagy Supports Breast Cancer Stem Cell Maintenance by Regulating IL6 Secretion. Mol. Cancer Res. 2015, 13, 651-658. [CrossRef] [PubMed]

205. Zhu, H.; Wang, D.; Liu, Y.; Su, Z.; Zhang, L.; Chen, F.; Zhou, Y.; Wu, Y.; Yu, M.; Zhang, Z.; et al. Role of the Hypoxia-inducible factor- 1 alpha induced autophagy in the conversion of non-stem pancreatic cancer cells into CD133+ pancreatic cancer stem-like cells. Cancer Cell Int. 2013, 13, 119. [CrossRef] [PubMed]

206. Sun, R.; Shen, S.; Zhang, Y.J.; Xu, C.F.; Cao, Z.T.; Wen, L.P.; Wang, J. Nanoparticle-facilitated autophagy inhibition promotes the efficacy of chemotherapeutics against breast cancer stem cells. Biomaterials 2016, 103, 44-55. [CrossRef] [PubMed]

207. Huang, H.; Song, J.; Liu, Z.; Pan, L.; Xu, G. Autophagy activation promotes bevacizumab resistance in glioblastoma by suppressing Akt/mTOR signaling pathway. Oncol. Lett. 2018, 15, 1487-1494. [CrossRef] [PubMed]

208. Golden, E.B.; Cho, H.Y.; Jahanian, A.; Hofman, F.M.; Louie, S.G.; Schonthal, A.H.; Chen, T.C. Chloroquine enhances temozolomide cytotoxicity in malignant gliomas by blocking autophagy. Neurosurg. Focus 2014, 37, E12. [CrossRef] [PubMed]

209. Fu, Y.; Chang, H.; Peng, X.; Bai, Q.; Yi, L.; Zhou, Y.; Zhu, J.; Mi, M. Resveratrol inhibits breast cancer stem-like cells and induces autophagy via suppressing Wnt/beta-catenin signaling pathway. PLoS ONE 2014, 9, e102535.

210. Hirsch, H.A.; Iliopoulos, D.; Tsichlis, P.N.; Struhl, K. Metformin selectively targets cancer stem cells, and acts together with chemotherapy to block tumor growth and prolong remission. Cancer Res. 2009, 69, 7507-7511. [CrossRef] [PubMed]

211. Del Barco, S.; Vazquez-Martin, A.; Cufi, S.; Oliveras-Ferraros, C.; Bosch-Barrera, J.; Joven, J.; Martin-Castillo, B.; Menendez, J.A. Metformin: multi-faceted protection against cancer. Oncotarget 2011, 2, 896-917. [CrossRef] [PubMed]

212. Takahashi, R.U.; Miyazaki, H.; Takeshita, F.; Yamamoto, Y.; Minoura, K.; Ono, M.; Kodaira, M.; Tamura, K.; Mori, M.; Ochiya, T. Loss of microRNA-27b contributes to breast cancer stem cell generation by activating ENPP1. Nat. Commun. 2015, 6, 7318. [CrossRef] [PubMed]

213. Shi, P.; Liu, W.; Wang, H.; Li, F.; Zhang, H.; Wu, Y.; Kong, Y.; Zhou, Z.; Wang, C.; et al. Metformin suppresses triple-negative breast cancer stem cells by targeting KLF5 for degradation. Cell Discov. 2017, 3, 17010. [CrossRef] [PubMed]

214. Sonnenblick, A.; Agbor-Tarh, D.; Bradbury, I.; Di Cosimo, S.; Azim, H.A., Jr.; Fumagalli, D.; Sarp, S.; Wolff, A.C.; Andersson, M.; Kroep, J.; et al. Impact of Diabetes, Insulin, and Metformin Use on the Outcome of Patients With Human Epidermal Growth Factor Receptor 2-Positive Primary Breast Cancer: Analysis From the ALTTO Phase III Randomized Trial. J. Clin. Oncol. 2017, 35, 1421-1429. [CrossRef] [PubMed]

215. Son, K.; Fujioka, S.; Iida, T.; Furukawa, K.; Fujita, T.; Yamada, H.; Chiao, P.J.; Yanaga, K. Doxycycline induces apoptosis in PANC-1 pancreatic cancer cells. Anticancer Res. 2009, 29, 3995-4003. [PubMed] 
216. Duivenvoorden, W.C.; Popovic, S.V.; Lhotak, S.; Seidlitz, E.; Hirte, H.W.; Tozer, R.G.; Singh, G. Doxycycline decreases tumor burden in a bone metastasis model of human breast cancer. Cancer Res. 2002, 62, 1588-1591. [PubMed]

217. De Francesco, E.M.; Maggiolini, M.; Tanowitz, H.B.; Sotgia, F.; Lisanti, M.P. Targeting hypoxic cancer stem cells (CSCs) with Doxycycline: Implications for optimizing anti-angiogenic therapy. Oncotarget 2017, 8 , 56126-56142. [CrossRef] [PubMed]

218. Yu, Y.; Xiao, C.H.; Tan, L.D.; Wang, Q.S.; Li, X.Q.; Feng, Y.M. Cancer-associated fibroblasts induce epithelial-mesenchymal transition of breast cancer cells through paracrine TGF-beta signalling. Br. J. Cancer 2014, 110, 724-732. [CrossRef]

219. Chen, W.J.; Ho, C.C.; Chang, Y.L.; Chen, H.Y.; Lin, C.A.; Ling, T.Y.; Yu, S.L.; Yuan, S.S.; Chen, Y.J.; Lin, C.Y.; et al. Cancer-associated fibroblasts regulate the plasticity of lung cancer stemness via paracrine signalling. Nat. Commun. 2014, 5, 3472. [CrossRef]

220. Yang, W.C.; Chen, H.W.; Au, H.K.; Chang, C.W.; Huang, C.T.; Yen, Y.H.; Tzeng, C.R. Serum and endometrial markers. Best Pract Res. Clin. Obstet. Gynaecol. 2004, 18, 305-318. [CrossRef]

221. Au, H.K.; Chang, J.H.; Wu, Y.C.; Kuo, Y.C.; Chen, Y.H.; Lee, W.C.; Chang, T.S.; Lan, P.C.; Kuo, H.C.; Lee, K.L.; et al. TGF-betaI Regulates Cell Migration through Pluripotent Transcription Factor OCT4 in Endometriosis. PLoS ONE 2015, 10, e0145256. [CrossRef] [PubMed]

222. Chang, T.S.; Chen, C.L.; Wu, Y.C.; Liu, J.J.; Kuo, Y.C.; Lee, K.F.; Lin, S.Y.; Lin, S.E.; Tung, S.Y.; Kuo, L.M.; et al. Inflammation Promotes Expression of Stemness-Related Properties in HBV-Related Hepatocellular Carcinoma. PLoS ONE 2016, 11, e0149897. [CrossRef] [PubMed]

223. Chang, T.S.; Wu, Y.C.; Chi, C.C.; Su, W.C.; Chang, P.J.; Lee, K.F.; Tung, T.H.; Wang, J.; Liu, J.J.; Tung, S.Y.; et al. Activation of IL6/IGFIR confers poor prognosis of HBV-related hepatocellular carcinoma through induction of OCT4/NANOG expression. Clin. Cancer Res. 2015, 21, 201-210. [CrossRef] [PubMed]

224. Huang, Y.H.; Lin, M.H.; Wang, P.C.; Wu, Y.C.; Chiang, H.L.; Wang, Y.L.; Chang, J.H.; Huang, Y.K.; Gu, S.Y.; Ho, H.N.; et al. Hypoxia inducible factor 2alpha/insulin-like growth factor receptor signal loop supports the proliferation and Oct-4 maintenance of mouse germline stem cells. Mol. Hum. Reprod. 2014, 20, 526-537. [CrossRef] [PubMed]

225. Wong, V.W.; Yu, J.; Cheng, A.S.; Wong, G.L.; Chan, H.Y.; Chu, E.S.; Ng, E.K.; Chan, F.K.; Sung, J.J.; Chan, H.L. High serum interleukin-6 level predicts future hepatocellular carcinoma development in patients with chronic hepatitis B. Int. J. Cancer 2009, 124, 2766-2770. [CrossRef] [PubMed]

226. Kuo, C.N.; Pan, J.J.; Huang, Y.W.; Tsai, H.J.; Chang, W.C. Association between Nonsteroidal Anti-Inflammatory Drugs and Colorectal Cancer: A Population-Based Case-Control Study. Cancer Epidemiol. Biomarkers Prev. 2018, 27, 737-745. [CrossRef] [PubMed]

227. Moon, C.M.; Kwon, J.H.; Kim, J.S.; Oh, S.H.; Jin Lee, K.; Park, J.J.; Pil Hong, S.; Cheon, J.H.; Kim, T.I.; Kim, W.H. Nonsteroidal anti-inflammatory drugs suppress cancer stem cells via inhibiting PTGS2 (cyclooxygenase 2) and NOTCH/HES1 and activating PPARG in colorectal cancer. Int. J. Cancer 2014, 134, 519-529. [CrossRef] [PubMed]

228. Valverde, A.; Penarando, J.; Canas, A.; Lopez-Sanchez, L.M.; Conde, F.; Hernandez, V.; Peralbo, E.; Lopez-Pedrera, C.; de la Haba-Rodriguez, J.; Aranda, E.; et al. Simultaneous inhibition of EGFR/VEGFR and cyclooxygenase-2 targets stemness-related pathways in colorectal cancer cells. PLoS ONE 2015, 10, e0131363. [CrossRef] [PubMed]

229. Doherty, M.R.; Cheon, H.; Junk, D.J.; Vinayak, S.; Varadan, V.; Telli, M.L.; Ford, J.M.; Stark, G.R.; Jackson, M.W. Interferon-beta represses cancer stem cell properties in triple-negative breast cancer. Proc. Natl. Acad. Sci. USA 2017, 114, 13792-13797. [CrossRef]

230. Provenzano, P.P.; Cuevas, C.; Chang, A.E.; Goel, V.K.; Von Hoff, D.D.; Hingorani, S.R. Enzymatic targeting of the stroma ablates physical barriers to treatment of pancreatic ductal adenocarcinoma. Cancer Cell 2012, 21, 418-429. [CrossRef]

231. Hermann, P.C.; Sancho, P.; Canamero, M.; Martinelli, P.; Madriles, F.; Michl, P.; Gress, T.; de Pascual, R.; Gandia, L.; Guerra, C.; et al. Nicotine promotes initiation and progression of KRAS-induced pancreatic cancer via Gata6-dependent dedifferentiation of acinar cells in mice. Gastroenterology 2014, 147, 1119-1133 e1114. [CrossRef] [PubMed]

232. Schaal, C.M.; Bora-Singhal, N.; Kumar, D.M.; Chellappan, S.P. Regulation of Sox2 and stemness by nicotine and electronic-cigarettes in non-small cell lung cancer. Mol. Cancer 2018, 17, 149. [CrossRef] [PubMed] 
233. Maki, R.G. Small is beautiful: insulin-like growth factors and their role in growth, development, and cancer. J. Clin. Oncol. 2010, 28, 4985-4995. [CrossRef] [PubMed]

234. Bendall, S.C.; Stewart, M.H.; Menendez, P.; George, D.; Vijayaragavan, K.; Werbowetski-Ogilvie, T.; Ramos-Mejia, V.; Rouleau, A.; Yang, J.; Bosse, M.; et al. IGF and FGF cooperatively establish the regulatory stem cell niche of pluripotent human cells in vitro. Nature 2007, 448, 1015-1021. [CrossRef] [PubMed]

235. Trajkovic-Arsic, M.; Kalideris, E.; Siveke, J.T. The role of insulin and IGF system in pancreatic cancer. J. Mol. Endocrinol. 2013, 50, R67-R74. [CrossRef] [PubMed]

236. Li, Z.J.; Ying, X.J.; Chen, H.L.; Ye, P.J.; Chen, Z.L.; Li, G.; Jiang, H.F.; Liu, J.; Zhou, S.Z. Insulin-like growth factor-1 induces lymphangiogenesis and facilitates lymphatic metastasis in colorectal cancer. World J. Gastroenterol. 2013, 19, 7788-7794. [CrossRef] [PubMed]

237. Kubasiak, J.C.; Seder, C.W.; Pithadia, R.; Basu, S.; Fhied, C.; Phillips, W.W.; Daly, S.; Shersher, D.D.; Yoder, M.A.; Chmielewski, G.; et al. Value of circulating insulin-like growth factor-associated proteins for the detection of stage I non-small cell lung cancer. J. Thorac. Cardiovasc. Surg. 2015, 149, 727-734 e721-723, discussion 734. [CrossRef] [PubMed]

238. Huang, Y.F.; Cheng, W.F.; Wu, Y.P.; Cheng, Y.M.; Hsu, K.F.; Chou, C.Y. Circulating IGF system and treatment outcome in epithelial ovarian cancer. Endocr. Relat. Cancer 2014, 21, 217-229. [CrossRef]

239. Cao, Y.; Lindstrom, S.; Schumacher, F.; Stevens, V.L.; Albanes, D.; Berndt, S.; Boeing, H.; Bueno-de-Mesquita, H.B.; Canzian, F.; Chamosa, S.; et al. Insulin-like growth factor pathway genetic polymorphisms, circulating IGF1 and IGFBP3, and prostate cancer survival. J. Natl. Cancer Inst. 2014, 106, dju085. [CrossRef]

240. Bruchim, I.; Sarfstein, R.; Werner, H. The IGF Hormonal Network in Endometrial Cancer: Functions, Regulation, and Targeting Approaches. Front. Endocrinol. (Lausanne) 2014, 5, 76. [CrossRef]

241. Ireland, L.; Santos, A.; Ahmed, M.S.; Rainer, C.; Nielsen, S.R.; Quaranta, V.; Weyer-Czernilofsky, U.; Engle, D.D.; Perez-Mancera, P.A.; Coupland, S.E.; et al. Chemoresistance in Pancreatic Cancer Is Driven by Stroma-Derived Insulin-Like Growth Factors. Cancer Res. 2016, 76, 6851-6863. [CrossRef] [PubMed]

242. Li, B.; Tsao, S.W.; Chan, K.W.; Ludwig, D.L.; Novosyadlyy, R.; Li, Y.Y.; He, Q.Y.; Cheung, A.L. Id1-induced IGF-II and its autocrine/endocrine promotion of esophageal cancer progression and chemoresistance-implications for IGF-II and IGF-IR-targeted therapy. Clin. Cancer Res. 2014, 20, 2651-2662. [CrossRef] [PubMed]

243. Singh, R.K.; Gaikwad, S.M.; Jinager, A.; Chaudhury, S.; Maheshwari, A.; Ray, P. IGF-1R inhibition potentiates cytotoxic effects of chemotherapeutic agents in early stages of chemoresistant ovarian cancer cells. Cancer Lett. 2014, 354, 254-262. [CrossRef] [PubMed]

244. Cerna, M.; Narsanska, A.; Treska, V.; Kucera, R.; Topolcan, O. IGF1 and tumor markers in different breast cancer stages. Rozhl. Chir. 2011, 90, 688-694. [PubMed]

245. Litzenburger, B.C.; Creighton, C.J.; Tsimelzon, A.; Chan, B.T.; Hilsenbeck, S.G.; Wang, T.; Carboni, J.M.; Gottardis, M.M.; Huang, F.; Chang, J.C.; et al. High IGF-IR activity in triple-negative breast cancer cell lines and tumorgrafts correlates with sensitivity to anti-IGF-IR therapy. Clin. Cancer Res. 2011, 17, 2314-2327. [CrossRef] [PubMed]

246. Chang, W.W.; Lin, R.J.; Yu, J.; Chang, W.Y.; Fu, C.H.; Lai, A.; Yu, J.C.; Yu, A.L. The expression and significance of insulin-like growth factor-1 receptor and its pathway on breast cancer stem/progenitors. Breast Cancer Res. 2013, 15, R39. [CrossRef] [PubMed]

247. Singh, R.K.; Dhadve, A.; Sakpal, A.; De, A.; Ray, P. An active IGF-1R-AKT signaling imparts functional heterogeneity in ovarian CSC population. Sci. Rep. 2016, 6, 36612. [CrossRef] [PubMed]

248. Lee, C.H.; Chang, Y.C.; Chen, C.S.; Tu, S.H.; Wang, Y.J.; Chen, L.C.; Chang, Y.J.; Wei, P.L.; Chang, H.W.; Chang, C.H.; et al. Crosstalk between nicotine and estrogen-induced estrogen receptor activation induces alpha9-nicotinic acetylcholine receptor expression in human breast cancer cells. Breast Cancer Res. Treat. 2011, 129, 331-345. [CrossRef]

249. Aali, N.; Motalleb, G. The effect of nicotine on the expressions of the alpha7 nicotinic receptor gene and Bax and $\mathrm{Bcl}-2$ proteins in the mammary gland epithelial-7 breast cancer cell line and its relationship to drug resistance. Cell Mol. Biol. Lett. 2015, 20, 948-964. [CrossRef]

250. Davis, R.; Rizwani, W.; Banerjee, S.; Kovacs, M.; Haura, E.; Coppola, D.; Chellappan, S. Nicotine promotes tumor growth and metastasis in mouse models of lung cancer. PLoS ONE 2009, 4, e7524. [CrossRef] 
251. Heeschen, C.; Jang, J.J.; Weis, M.; Pathak, A.; Kaji, S.; Hu, R.S.; Tsao, P.S.; Johnson, F.L.; Cooke, J.P. Nicotine stimulates angiogenesis and promotes tumor growth and atherosclerosis. Nat. Med. 2001, 7, 833-839. [CrossRef] [PubMed]

252. Lee, C.H.; Huang, C.S.; Chen, C.S.; Tu, S.H.; Wang, Y.J.; Chang, Y.J.; Tam, K.W.; Wei, P.L.; Cheng, T.C.; $\mathrm{Chu}$, J.S.; et al. Overexpression and activation of the alpha9-nicotinic receptor during tumorigenesis in human breast epithelial cells. J. Natl. Cancer Inst. 2010, 102, 1322-1335. [CrossRef] [PubMed]

253. Chen, R.J.; Ho, Y.S.; Guo, H.R.; Wang, Y.J. Rapid activation of Stat3 and ERK1/2 by nicotine modulates cell proliferation in human bladder cancer cells. Toxicol. Sci. 2008, 104, 283-293. [CrossRef] [PubMed]

254. Nishioka, T.; Kim, H.S.; Luo, L.Y.; Huang, Y.; Guo, J.; Chen, C.Y. Sensitization of epithelial growth factor receptors by nicotine exposure to promote breast cancer cell growth. Breast Cancer Res. 2011, 13, R113. [CrossRef] [PubMed]

255. Ho, Y.S.; Chen, C.H.; Wang, Y.J.; Pestell, R.G.; Albanese, C.; Chen, R.J.; Chang, M.C.; Jeng, J.H.; Lin, S.Y.; Liang, Y.C.; et al. Tobacco-specific carcinogen 4-(methylnitrosamino)-1-(3-pyridyl)-1-butanone (NNK) induces cell proliferation in normal human bronchial epithelial cells through NFkappaB activation and cyclin D1 up-regulation. Toxicol. Appl. Pharmacol. 2005, 205, 133-148. [CrossRef] [PubMed]

256. Pillai, S.; Chellappan, S. alpha7 nicotinic acetylcholine receptor subunit in angiogenesis and epithelial to mesenchymal transition. Curr. Drug Targets 2012, 13, 671-679. [PubMed]

257. Lien, Y.C.; Wang, W.; Kuo, L.J.; Liu, J.J.; Wei, P.L.; Ho, Y.S.; Ting, W.C.; Wu, C.H.; Chang, Y.J. Nicotine promotes cell migration through alpha7 nicotinic acetylcholine receptor in gastric cancer cells. Ann. Surg. Oncol. 2011, 18, 2671-2679. [CrossRef] [PubMed]

258. Momi, N.; Ponnusamy, M.P.; Kaur, S.; Rachagani, S.; Kunigal, S.S.; Chellappan, S.; Ouellette, M.M.; Batra, S.K. Nicotine/cigarette smoke promotes metastasis of pancreatic cancer through alpha7nAChR-mediated MUC4 upregulation. Oncogene 2013, 32, 1384-1395. [CrossRef]

259. Wang, W.; Chin-Sheng, H.; Kuo, L.J.; Wei, P.L.; Lien, Y.C.; Lin, F.Y.; Liu, H.H.; Ho, Y.S.; Wu, C.H.; Chang, Y.J. NNK enhances cell migration through alpha7-nicotinic acetylcholine receptor accompanied by increased of fibronectin expression in gastric cancer. Ann. Surg. Oncol. 2012, 19, S580-S588. [CrossRef]

260. Wei, P.L.; Chang, Y.J.; Ho, Y.S.; Lee, C.H.; Yang, Y.Y.; An, J.; Lin, S.Y. Tobacco-specific carcinogen enhances colon cancer cell migration through alpha7-nicotinic acetylcholine receptor. Ann. Surg. 2009, 249, 978-985. [CrossRef]

261. Chen, R.J.; Ho, Y.S.; Guo, H.R.; Wang, Y.J. Long-term nicotine exposure-induced chemoresistance is mediated by activation of Stat 3 and downregulation of ERK1/2 via $\mathrm{nAChR}$ and beta-adrenoceptors in human bladder cancer cells. Toxicol. Sci. 2010, 115, 118-130. [CrossRef] [PubMed]

262. Trevino, J.G.; Pillai, S.; Kunigal, S.; Singh, S.; Fulp, W.J.; Centeno, B.A.; Chellappan, S.P. Nicotine induces inhibitor of differentiation-1 in a Src-dependent pathway promoting metastasis and chemoresistance in pancreatic adenocarcinoma. Neoplasia 2012, 14, 1102-1114. [CrossRef]

263. Guha, P.; Bandyopadhyaya, G.; Polumuri, S.K.; Chumsri, S.; Gade, P.; Kalvakolanu, D.V.; Ahmed, H. Nicotine promotes apoptosis resistance of breast cancer cells and enrichment of side population cells with cancer stem cell-like properties via a signaling cascade involving galectin-3, alpha9 nicotinic acetylcholine receptor and STAT3. Breast Cancer Res. Treat. 2014, 145, 5-22. [CrossRef] [PubMed]

264. Al-Wadei, M.H.; Banerjee, J.; Al-Wadei, H.A.; Schuller, H.M. Nicotine induces self-renewal of pancreatic cancer stem cells via neurotransmitter-driven activation of sonic hedgehog signalling. Eur. J. Cancer 2016, 52, 188-196. [CrossRef] [PubMed]

265. Yu, C.C.; Chang, Y.C. Enhancement of cancer stem-like and epithelial-mesenchymal transdifferentiation property in oral epithelial cells with long-term nicotine exposure: reversal by targeting SNAIL. Toxicol. Appl. Pharmacol. 2013, 266, 459-469. [CrossRef] [PubMed]

266. Hirata, N.; Sekino, Y.; Kanda, Y. Nicotine increases cancer stem cell population in MCF-7 cells. Biochem. Biophys. Res. Commun. 2010, 403, 138-143. [CrossRef]

267. Dinicola, S.; Morini, V.; Coluccia, P.; Proietti, S.; D’Anselmi, F.; Pasqualato, A.; Masiello, M.G.; Palombo, A.; De Toma, G.; Bizzarri, M.; et al. Nicotine increases survival in human colon cancer cells treated with chemotherapeutic drugs. Toxicol. In Vitro 2013, 27, 2256-2263. [CrossRef] [PubMed]

268. Cucina, A.; Dinicola, S.; Coluccia, P.; Proietti, S.; D’Anselmi, F.; Pasqualato, A.; Bizzarri, M. Nicotine stimulates proliferation and inhibits apoptosis in colon cancer cell lines through activation of survival pathways. J. Surg. Res. 2012, 178, 233-241. [CrossRef] 
269. Wong, H.P.; Yu, L.; Lam, E.K.; Tai, E.K.; Wu, W.K.; Cho, C.H. Nicotine promotes cell proliferation via alpha7-nicotinic acetylcholine receptor and catecholamine-synthesizing enzymes-mediated pathway in human colon adenocarcinoma HT-29 cells. Toxicol. Appl. Pharmacol. 2007, 221, 261-267. [CrossRef]

270. Hsieh, Y.C.; Lee, C.H.; Tu, S.H.; Wu, C.H.; Hung, C.S.; Hsieh, M.C.; Chuang, C.W.; Ho, Y.S.; Chiou, H.Y. CHRNA9 polymorphisms and smoking exposure synergize to increase the risk of breast cancer in Taiwan. Carcinogenesis 2014, 35, 2520-2525. [CrossRef]

271. Valor, L.M.; Castillo, M.; Ortiz, J.A.; Criado, M. Transcriptional regulation by activation and repression elements located at the $5^{\prime}$-noncoding region of the human alpha9 nicotinic receptor subunit gene. J. Biol. Chem. 2003, 278, 37249-37255. [CrossRef] [PubMed]

272. Lin, C.Y.; Lee, C.H.; Chuang, Y.H.; Lee, J.Y.; Chiu, Y.Y.; Wu Lee, Y.H.; Jong, Y.J.; Hwang, J.K.; Huang, S.H.; Chen, L.C.; et al. Membrane protein-regulated networks across human cancers. Nat. Commun. 2019, 10, 3131. [CrossRef] [PubMed]

273. Heiser, L.M.; Sadanandam, A.; Kuo, W.L.; Benz, S.C.; Goldstein, T.C.; Ng, S.; Gibb, W.J.; Wang, N.J.; Ziyad, S.; Tong, F.; et al. Subtype and pathway specific responses to anticancer compounds in breast cancer. Proc. Natl. Acad. Sci. USA 2012, 109, 2724-2729. [CrossRef] [PubMed]

274. Barretina, J.; Caponigro, G.; Stransky, N.; Venkatesan, K.; Margolin, A.A.; Kim, S.; Wilson, C.J.; Lehar, J.; Kryukov, G.V.; Sonkin, D.; et al. The Cancer Cell Line Encyclopedia enables predictive modelling of anticancer drug sensitivity. Nature 2012, 483, 603-607. [CrossRef] [PubMed]

275. Brough, R.; Frankum, J.R.; Sims, D.; Mackay, A.; Mendes-Pereira, A.M.; Bajrami, I.; Costa-Cabral, S.; Rafiq, R.; Ahmad, A.S.; Cerone, M.A.; et al. Functional viability profiles of breast cancer. Cancer Discov. 2011, 1, 260-273. [CrossRef]

276. Daemen, A.; Griffith, O.L.; Heiser, L.M.; Wang, N.J.; Enache, O.M.; Sanborn, Z.; Pepin, F.; Durinck, S.; Korkola, J.E.; Griffith, M.; et al. Modeling precision treatment of breast cancer. Genome. Biol. 2013, 14, R110. [CrossRef]

277. Gautam, P.; Karhinen, L.; Szwajda, A.; Jha, S.K.; Yadav, B.; Aittokallio, T.; Wennerberg, K. Identification of selective cytotoxic and synthetic lethal drug responses in triple negative breast cancer cells. Mol. Cancer 2016, 15, 34. [CrossRef]

278. Gautam, P.; Jaiswal, A.; Aittokallio, T.; Al-Ali, H.; Wennerberg, K. Phenotypic Screening Combined with Machine Learning for Efficient Identification of Breast Cancer-Selective Therapeutic Targets. Cell Chem. Biol. 2019, 26, 970-979. [CrossRef] 